https://doi.org/10.5800/GT-2018-9-3-0377

\title{
HELIOGEODYNAMICS AND SEISMICITY IN PRIBAIKALIE
}

\author{
K. G. Levi1, A. I. Miroshnichenko¹, V. V. Chechelnitsky², G. M. Ruzhnikov³ \\ ${ }^{1}$ Institute of the Earth's Crust, Siberian Branch of RAS, Irkutsk, Russia \\ ${ }^{2}$ Baikal Branch of Federal Research Center 'Geophysical Survey of RAS', Irkutsk, Russia \\ 3 V.M. Matrosov Institute for System Dynamics and Control Theory, Siberian Branch of RAS, Irkutsk, Russia
}

\begin{abstract}
The field of earthquake epicentres of Pribaikalie (Russia) is reconstructed from the data of historical and instrumental monitoring of earthquakes. The analysis shows that seismic events in the study area are distributed irregularly in space and time. The seismic process in Pribaikalie is investigated through the prism of seismic structures in the lithosphere; the irregular occurrence of seismic events in time is considered with reference to seismic weather and climate; and the causes of periodic activations of the seismic process are discovered in relation to the external effects on the Earth's physical fields from cosmic and solar processes. It is proposed to classify the seismic structures as specific geometric objects located in the lithosphere. Such objects are viewed as abstract structural elements. Some regular features are noted in the occurrence of seismic events. It is revealed that the seismic process in time shows a similarity with the course of hydrometeorological processes, which is reflected in the periodicity of elastic energy release, if only the change in the number of earthquakes (of different energy classes) in time is analysed by years. An evidently regular time pattern of seismically active periods suggests that the seismic process is influenced by some external factors. In this study, we apply the concepts of heliogeodynamics, space climate and weather to investigate such factors.
\end{abstract}

Key words: heliogeodynamics; space weather and climate; solar activity; geomagnetic activity; auroras and seismicity; Pribaikalie

\section{RESEARCH ARTICLE}

Handling Editor: V.A. Sankov
Received: June 8, 2018

Revised: July 17, 2018

Accepted: July 23, 2018

For citation: Levi K.G., Miroshnichenko A.I., Chechelnitsky V.V., Ruzhnikov G.M., 2018. Heliogeodynamics and seismicity in Pribaikalie. Geodynamics \& Tectonophysics 9 (3), 927-946. doi:10.5800/GT-2018-9-3-0377.

Для цитирования: Леви К.Г., Мирошниченко А.И., Чечельницкий В.В., Ружников Г.М. Гелиогеодинамика и сейсмичность в Прибайкалье // Геодинамика и тектонофизика. 2018. Т. 9. № 3. С. 927-946. doi:10.5800/GT-2018-9-3-0377. 


\title{
ГЕЛИОГЕОДИНАМИКА И СЕЙСМИЧНОСТЬ В ПРИБАЙКАЛЬЕ
}

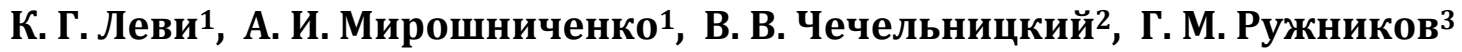 \\ ${ }^{1}$ Институт земной коры СО РАН, Иркутск, Россия \\ ${ }^{2}$ Байкальский филиал Федерального исследовательского центра \\ «Единая геофизическая служба РАН», Иркутск, Россия \\ ${ }^{3}$ Институт динамики систем и теории управления им. В.М. Матросова СО РАН, Иркутск, Россия
}

\begin{abstract}
Аннотация: Анализ эпицентрального поля землетрясений в Прибайкалье выявил пространственно-временную неравномерность распределения сейсмических событий. Это позволило рассмотреть развитие сейсмического процесса через призму сейсмических структур литосферы, а неравномерность проявления событий по времени - в рамках сейсмической погоды и климата. Причины периодических активизаций сейсмического процесса связаны с внешним воздействием на физические поля Земли космических и солнечных процессов. В рамках сказанного дается классификация сейсмических структур как неких геометрических объектов, располагающихся в теле литосферы и являющихся ее абстрактными структурными элементами. Рассмотрены некоторые закономерности проявления сейсмических событий. Временной ход сейсмического процесса проявляет сходство с протеканием гидрометеорологических процессов, что находит свое отражение в периодичности реализации упругой энергии, если только рассматривать изменение во времени числа землетрясений различных энергетических классов по годам. Использованы материалы исторического и инструментального мониторинга землетрясений в Прибайкалье. Устойчивая периодичность сейсмических активизаций наводит на мысль о том, что на ход процесса влияют некие внешние факторы, рассматриваемые в рамках концепций гелиогеодинамики, космического климата и погоды.
\end{abstract}

Ключевые слова: гелиогеодинамика; космическая погода и климат; солнечная активность; геомагнитная активность; полярные сияния и сейсмичность; Прибайкалье

\section{1. ВВЕДЕНИЕ}

В 1979 г. по инициативе д.г.-м.н., профессора С.И. Шермана и при поддержке зам. директора ИЗК СО АН СССР д.г.-м.н. О.В. Павлова в институте была создана лаборатория тектонофизики, в задачи которой входило изучение физических закономерностей разломообразования в земной коре.

В данной публикации мы остановимся на влиянии вариаций космического климата на течение сейсмического процесса в Прибайкалье - изменения «сейсмической погоды». Термин возник в 1995 г., когда коллектив геофизиков ИЗК СО РАН, после землетрясений в мае на о-ве Сахалин и в июне - в Тункинской долине (Юго-Западное Прибайкалье) приступил к созданию научно-исследовательской программы «Сейсмобезопасность Иркутской области». К.Г. Леви, В.В. Ружич впервые заговорили о «сейсмической погоде» и ее прогнозе. Тогда мы старательно уходили от конкретизации работ по средне- и краткосрочному прогнозу землетрясений, отчетливо понимая, что на имеющемся уровне знаний он плохо достижим. Это была определенная осторожность в отношении реализации подходов к прогнозу землетрясений в целом. Однако тогда понятию «сейсмическая погода» четкого определения дано не было. Оно было приведено позже в нашей публикации [Levi, 2007]. Термины «климат», «погода» и «буря (шторм)» были заимствованы из климатологии и метеорологии, поскольку нам казалось, что они адекватно отражают сущность временных флуктуаций сейсмического (или какого-либо иного) процесса. Пояснения к терминам «космическая» и «сейсмическая» погода мы приведем ниже.

\section{2. СТРУКТУРА СЕЙСМИЧНОСТИ В ПРИБАЙКАЛЬЕ}

База данных о сейсмических событиях, в Прибайкалье содержит около 1310 исторических сообщений об ощутимых землетрясениях. Первая сейсмическая станция в г. Иркутске появилась в 1901 г., а полноценная сеть сейсмических наблюдений в регионе начала формироваться в 1959 г. (рис. 1).

Прогноз сильных сейсмических событий в Прибайкалье с высокой достоверностью вряд ли возможен из-за непродолжительности инструментального мониторинга (около 60 лет). Однако ход сейсмичности в первом приближении можно восстановить по историческим хроникам, которые приводят сведения об ощутимых землетрясениях в данном регионе (рис. 2) [Zadonina, Levi, 2008]. 


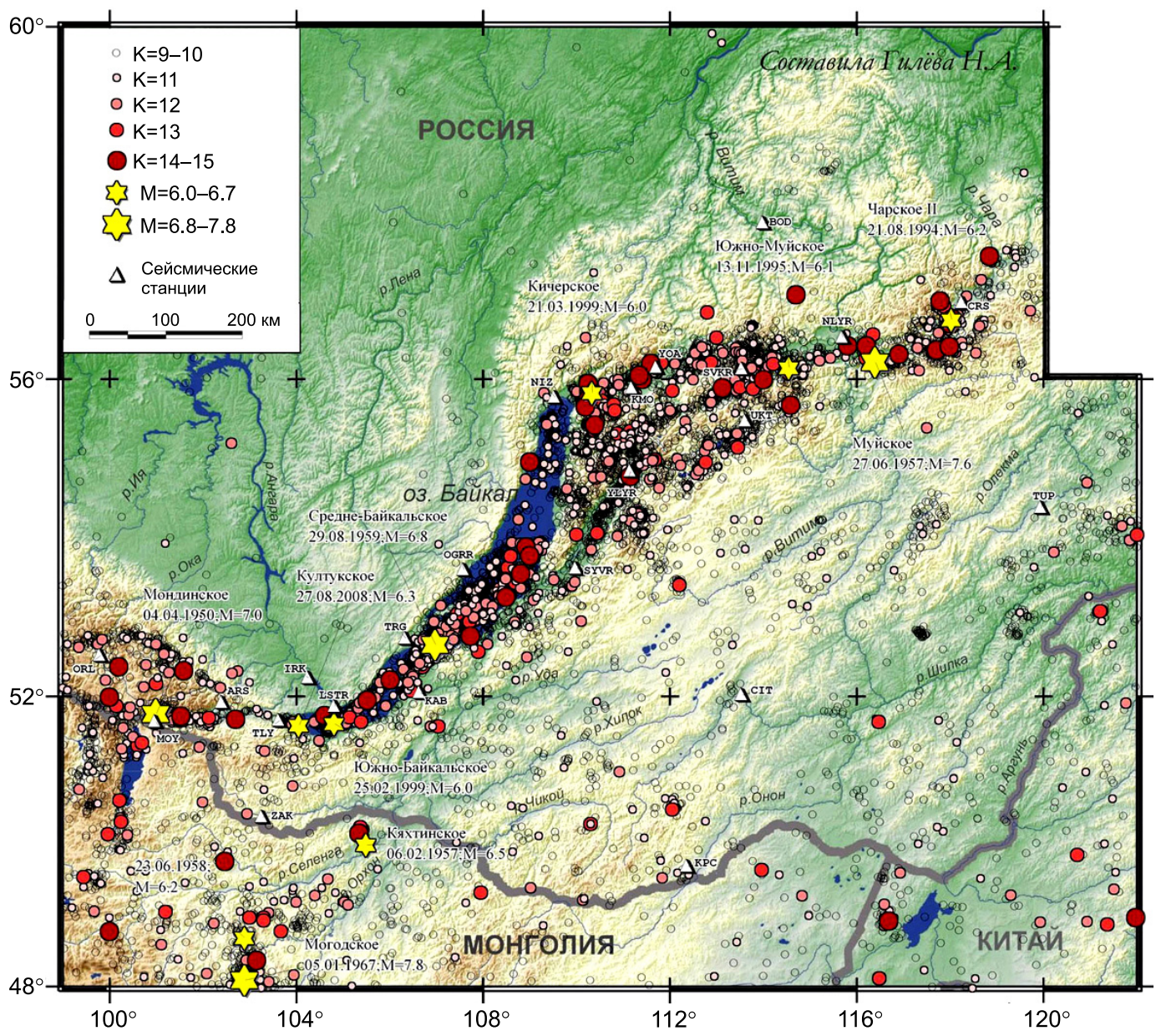

Рис. 1. Сейсмичность Прибайкалья за 1950-2009 гг. [Map of Earthquake Epicenters..., 2009].

|Fig. 1. Seismicity of Pribaikalie in 1950-2009 [Map of Earthquake Epicenters..., 2009].

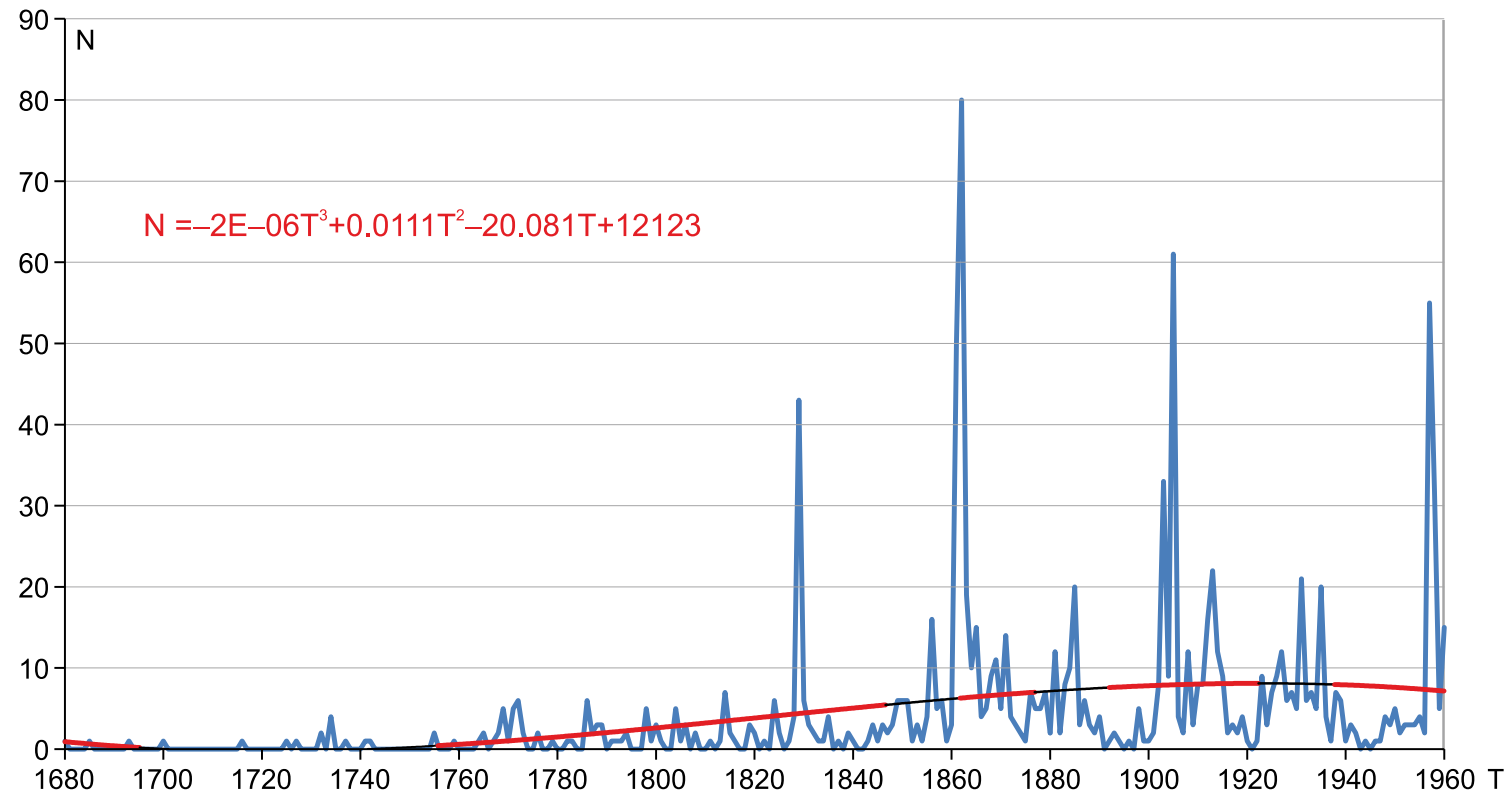

Рис. 2. Ход сейсмического процесса в Прибайкалье по материалам исторических хронологий. Красная кривая и уравнение - тренд изменения числа ощутимых сейсмических событий N по времени Т (годы).

Fig. 2. Seismic process in Pribaikalie, according to the historical chronological data. The red curve and the equation show a trend change in the number of perceptible seismic events $(\mathrm{N})$ by years $(\mathrm{T})$. 


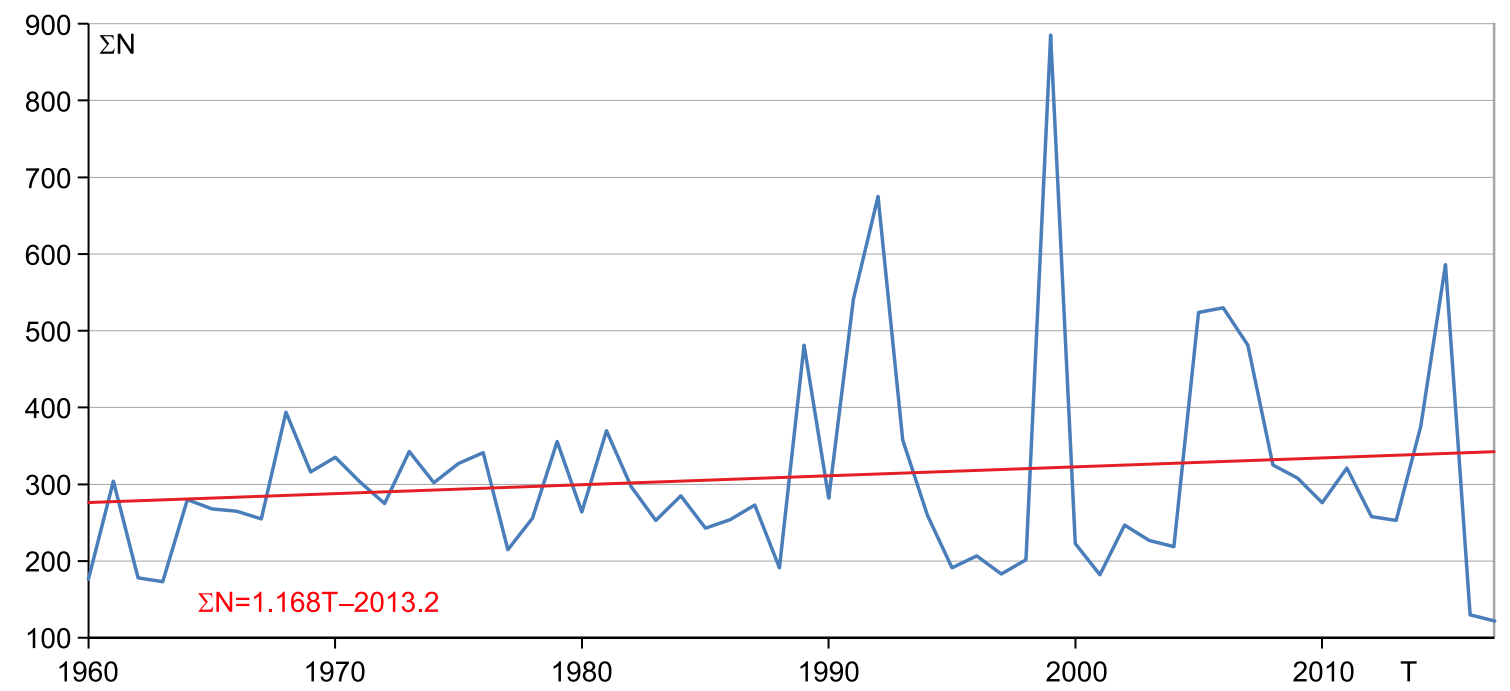

Рис. 3. Вариации частоты возникновения землетрясений К=9-17 за инструментальный период наблюдений в Прибайкалье (1960-2017 гг.). Красная кривая и уравнение - тренд изменения суммы чисел инструментально зарегистрированных сейсмических событий $\Sigma \mathrm{N}$ по времени T (годы).

Fig. 3. Variations in the frequency of earthquake occurrence $(K=9-17)$ in the period of instrumental observations in Pribaikalie (1960-2017). The red curve and the equation show a trend change in the total quantity of the instrumentally registered seismic events $(\Sigma \mathrm{N})$ by years $(\mathrm{T})$.

Кривая охватывает временной диапазон 16801960 гг., при этом совершенно очевидно то, что в ней имеются пропуски событий и она представляется достаточно достоверной лишь в интервале времени от 1820 г. до начала периода инструментальной регистрации землетрясений на сети сейсмических станций в Прибайкалье в 1960 г. На рис. 3 мы приводим ход сейсмического процесса в инструментальный период наблюдений.

Отчетливо выражены всплески сейсмической активности в 1829, 1862, 1905 и 1957-1959 гг., охарактеризовавшиеся возникновением сильных землетрясений. Отсюда следует, что в данном случае целесообразно говорить об изменении по времени некой сейсмической погоды и пытаться на этой основе учиться предсказывать ее «ухудшение» (читай увеличение числа событий на шкале времени) в некоторых интервалах времени. Постараемся показать на примере исторических и мониторинговых данных в Прибайкалье, какие, как нам кажется, характеристики могут выступать в качестве индикаторов изменения «сейсмического климата» и «сейсмической погоды». При этом мы не будем использовать сложный статистический аппарат, поскольку сами исходные данные страдают объективными дефектами, а «поправлять» их даже принятыми статистическими методами нерационально, поскольку это только испортит базу данных, «накрутив» на существующие в ней нерегулярные ошибки еще более нерегулярные, хотя и управляемые, новые ошибки.
Исторические хроники о землетрясениях представляют собой описания сейсмических событий по вызванным ими эффектам. Эти описания могут интерпретироваться с точностью \pm 1 балл по MSK64 [Medvedev et al., 1965]. Однако иногда приходится видеть в современных каталогах определение энергии исторических землетрясений с дробной частью. Этот некорректный подход к интерпретации подобных данных способен привести к глубоким заблуждениям некритически настроенных исследователей. Сопоставление исторических сообщений о землетрясениях показало, что упоминаемые ощутимые землетрясения относятся к событиям никак не ниже $K=12$, а это, в свою очередь, позволяет «сшить» базу исторических и мониторинговых данных в единое целое и получить интересные результаты.

При беглом рассмотрении рис. 1 возникает зрительное представление о хаотичности проявления сейсмического процесса. Это связано с традиционным отображением землетрясений кружками различного диаметра в зависимости от энергетического класса К. Если мы отойдем от этой традиции, отражая события только как факт точками, то обнаружим, что эпицентральное поле структурировано (рис. 4).

На рис. 4 отчетливо видны области уплотнения эпицентров, которые, вероятно, приурочены к каким-то неоднородностям среды, хрупко деформирующимся в действующем поле тектонических напряжений. Отсюда мы приходим к выводу о том, 


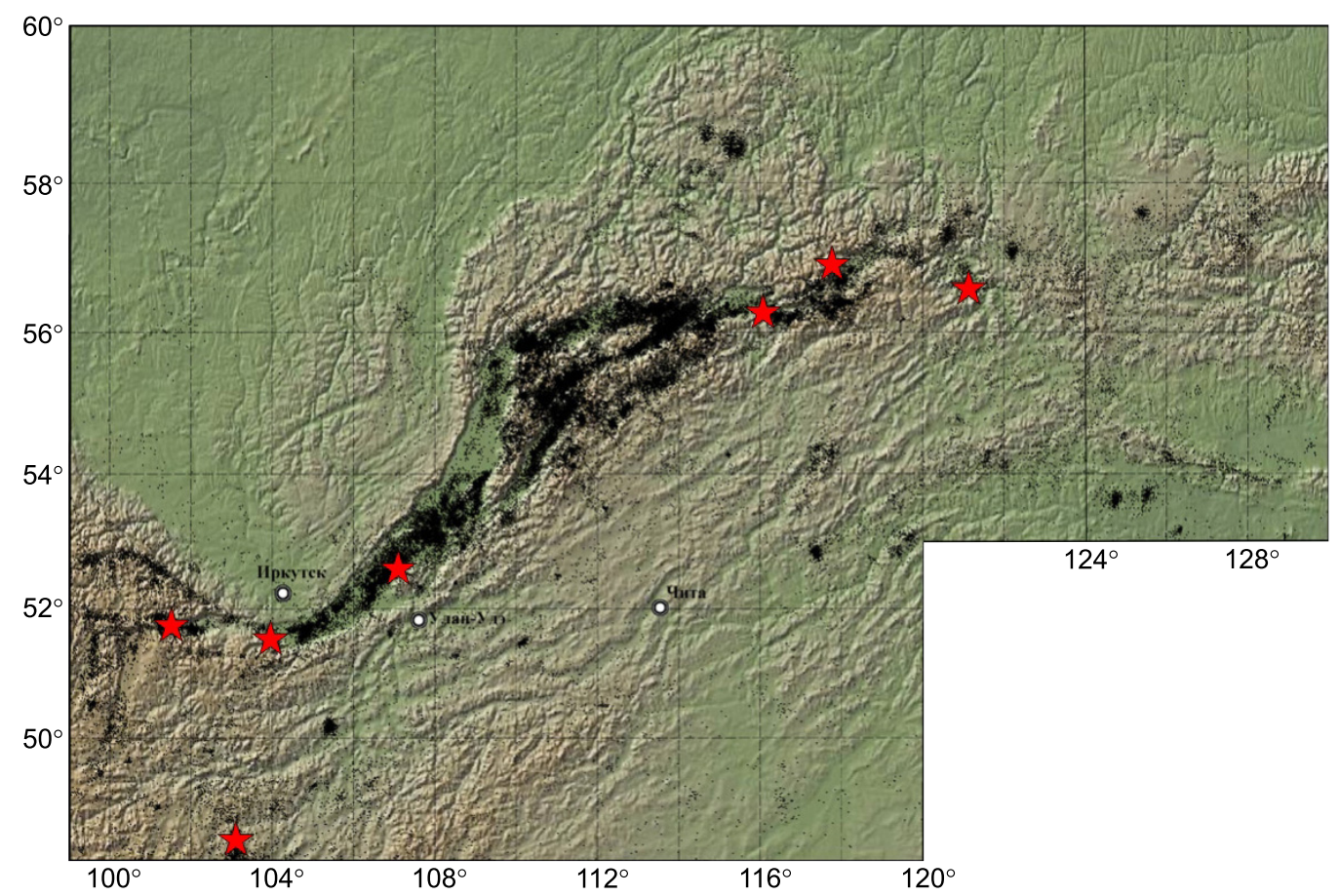

Рис. 4. Сейсмические структуры сейсмоактивной среды в Прибайкалье в версии эпицентрии. Красные звездочки эпицентры наиболее сильных землетрясений [Levi, Chechelnitsky, 2012; Levi, 2014].

Fig. 4. Seismic structures of the seismically active medium in Pribaikalie (epicenters version). Red stars show the epicenters of the strongest earthquakes [Levi, Chechelnitsky, 2012; Levi, 2014].

что в данном случае есть смысл говорить о «сейсмических» структурах литосферы.

\section{3. СЕЙСМИЧЕСКИЕ СТРУКТУРЫ ЛИТОСФЕРЫ}

Сейсмичность - явление многокомпонентного подчинения, обусловленное сложным взаимодействием механических и физико-химических процессов, происходящих в коре и литосфере Земли, поэтому целесообразно ее рассматривать как результат развития сейсмогеодинамической системы. При таком подходе сейсмичность рассматривается как отклик среды на сложные механические и физико-химические перестройки в процессе тектонической активизации коры и литосферы.

В сейсмологии и сейсмотектонике принято несколько наименований той области литосферы, к которой приурочена основная масса землетрясений. Это - «фокальный слой», «сейсмоактивный объем», «очаговый слой», «сейсмогенерирующий слой», «сейсмоактивный слой», а также «собственные структуры сейсмичности», «сейсмические пояса и зоны Земли» и т.п. [Levi, 1987a, 1987b; Shebalin et al., 1987; Sherman et al., 2002; Sherman, Zlogodukhova, 2011; u $\partial p$.].

Отметим, что площадь литосферного слоя Земли несколько превышает площадь земного шара за счет погружающихся в зонах поддвига слэбов, которые подвержены разрушению, сопровождающемуся сейсмическим процессом. Литосфера Земли, с геофизической точки зрения, делится на два слоя, различных по своей реологии, - упругий (Le) и пластичный [Levi, 1987b, 1991]. Толщина этих слоев легко оценивается статистически, упругий слой тоньше под термоактивными областями литосферы и толще - под кратонами, эти значения изменяются от 35 до 120 км соответственно. Сейсмичность напрямую связана с упругим слоем литосферы, который при высоких скоростях деформаций способен хрупко разрушаться и порождать сейсмические эффекты. Если это так, то, говоря об упругом слое литосферы, мы невольно говорим о глобально развитом сейсмогенерирующем слое [Levi, $1987 a, 1987 c]$.

Область литосферы, где концентрируются сейсмические очаги, понимается разными авторами одинаково, но именуется по-разному. В то же время среди упомянутых понятий можно выделить два, различные по смысловому и физическому объему: сейсмогенерирующий слой (о нем мы упомянули выше) и сейсмоактивный (очаговый) слой (Ls). «Сейсмогенерирующий слой» может разрушаться не полностью, а лишь частично, что определяется общей геодинамической обстановкой в разных регионах, скоростями деформации, плотностью 


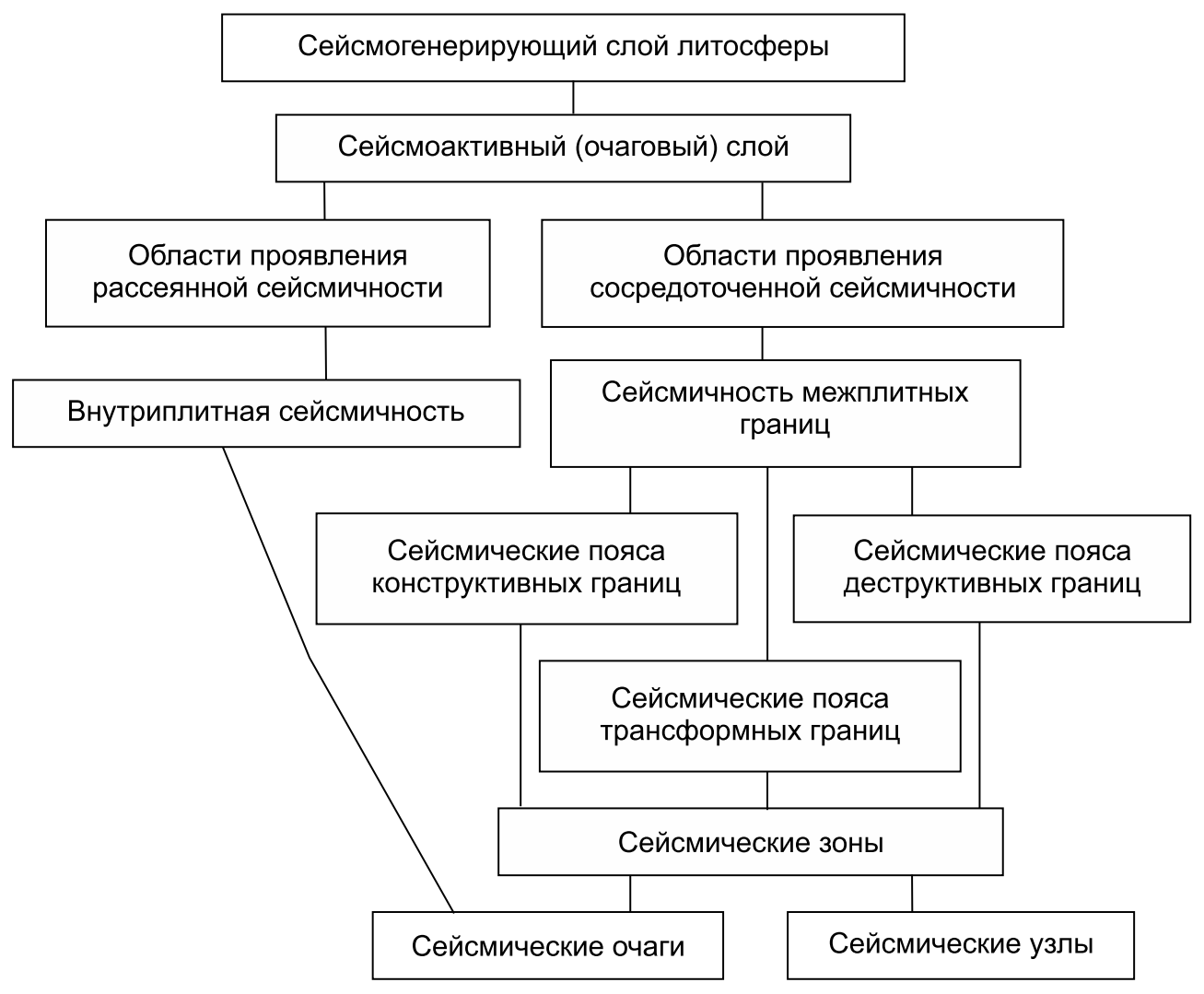

Рис. 5. Иерархическая система сейсмических структур.

Fig. 5. Hierarchical system of seismic structures.

теплового потока и т.д. В этом смысле он может быть сопоставлен с упругим слоем литосферы, толщина которого оценивается по материалам интерпретации гравиметрических данных или через знания о плотности глубинного теплового потока. Способы оценки параметров «термальной литосферы» (Lq), Le и Ls подробно рассмотрены в работе [Levi, 1991].

«Сейсмоактивный (очаговый) слой» - более узкое понятие и обозначает лишь ту часть сейсмогенерирующего слоя, в которой под действием деформаций образуется основная масса очагов землетрясений. При этом толщина очагового слоя меняется во времени, по мере того как меняются скорости деформаций упругого слоя литосферы. Параметры слоя оцениваются как результат сопоставления параметров «термальной», «упругой» литосферы и глубин залегания гипоцентров сильных землетрясений [Levi, 1991]. Толщина «термальной» литосферы оценивается из корреляци-

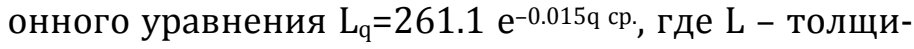
на литосферы по сейсмологическим данным в км, е - основание натуральных логарифмов, q ность глубинного теплового потока в мВт/км ${ }^{2}$. Толщина упругого слоя литосферы $\mathrm{L}_{e}$ оценивается гравиметрическими методами и связана с $\mathrm{L}_{\mathrm{q}}$ уравнением $\mathrm{L}_{\mathrm{e}}=\left(0.4 \mathrm{~L}_{\mathrm{q}}+3.2\right) \pm 14.6$ км. Деформации упругого слоя литосферы приводят к ее хрупкому разрушению, эффектом которого являются сейсмические события различной мощности. Именно по- следние и характеризуют толщину сейсмоактивного слоя. Опираясь на работы Н.В. Шебалина [Shebalin, 1971] и Ю.В. Ризниченко [Riznichenko, $1976 a, 1976 b]$ и зная глубинное распределение слабых землетрясений с максимальной глубиной гипоцентров, можно оценить толщину сейсмоактивного слоя. Располагая же данными о мощных землетрясениях, глубине их гипоцентров и размерах очагов, можно вычислить толщину сейсмоактивного слоя $\mathrm{H}_{\mathrm{eq}}$ из выражения $\mathrm{H}_{\mathrm{eq}}=1.5 \mathrm{R}_{\max }$, где $\mathrm{R}_{\max }-$ paдиус очага землетрясения по Ю.В. Ризниченко [Shebalin, 1971; Riznichenko, 1976a; 1976b].

С учетом глобального распространения сейсмоактивного слоя было бы неразумным представлять его повсеместно однородным. Действительно, анализ эпицентральных полей сильных землетрясений, т.е. тех землетрясений, которые являются основными носителями информации о геодинамической обстановке в тектоносфере, показывает, что распределение сейсмичности в слое весьма неравномерно, хотя и упорядоченно. Это, в свою очередь, требует акцентировать внимание на внутренней «сейсмической структуре» сейсмоактивного слоя. Под «сейсмическими структурами» понимаются геометризированные объемы тектоносферы, «заполненные» очагами известных, в результате инструментальных наблюдений, сильных землетрясений (рис. 5). Сейсмической структурой первого ранга является глобально распространенный сейсмоактивный слой. 


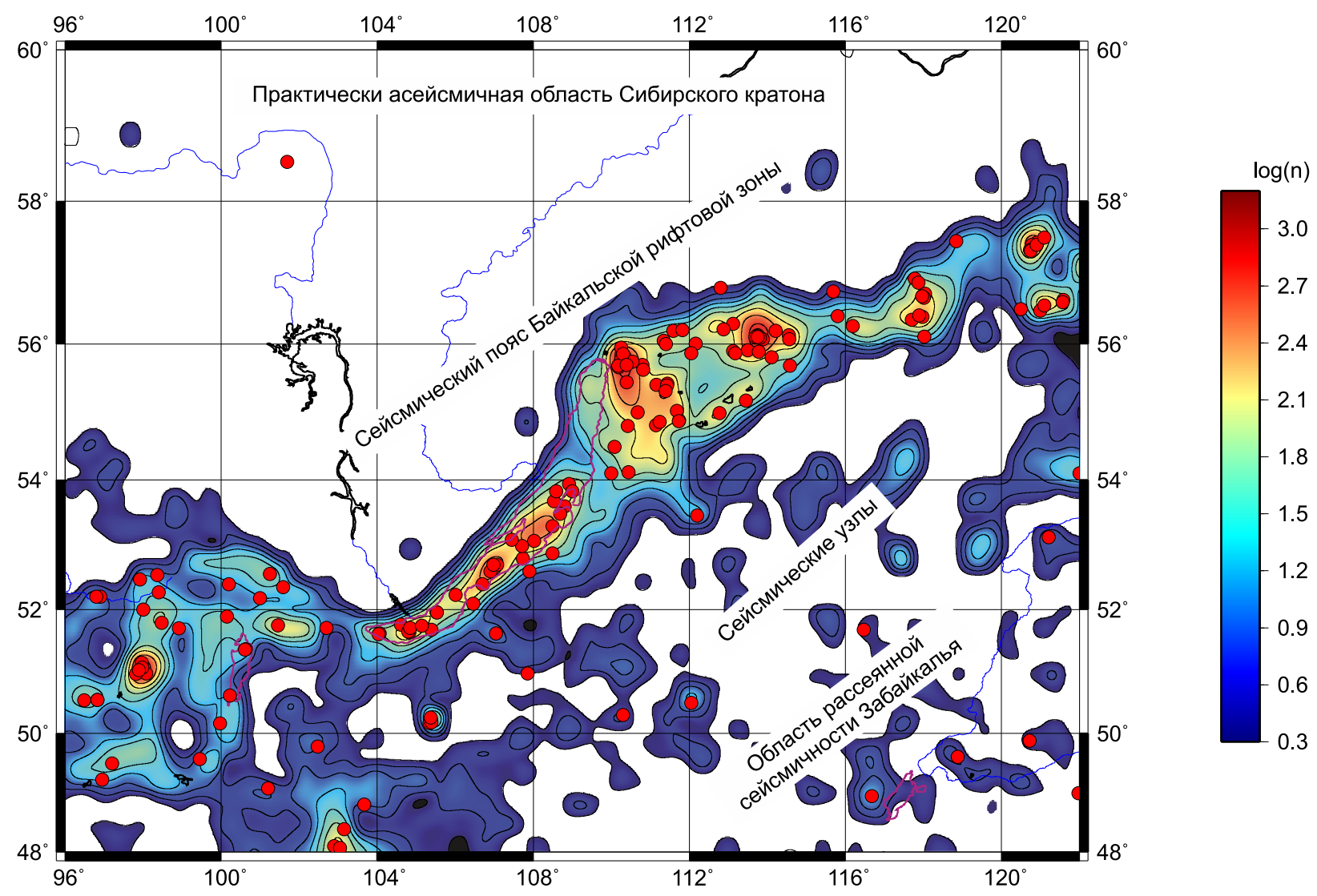

Рис. 6. Структура сейсмоактивного слоя литосферы в Прибайкалье в версии плотности эпицентров. Цветная шкала - концентрация эпицентров инструментально зарегистрированных землетрясений $\log (\mathrm{n})$; красные точки - землетрясения с $\mathrm{K} \geq 14$.

Fig. 6. Structure of the seismically active layer of the lithosphere in Pribaikalie (density of epicenters version). Colour scale concentration of epicenters of instrumentally registered earthquakes, $\log (\mathrm{n})$; red dots $-K \geq 14$ earthquakes.

На базе неравномерности распределения очагов сильных землетрясений в сейсмоактивном слое можно выделить сейсмоактивные структуры второго ранга - сейсмические пояса, в которых сейсмичность носит сосредоточенный характер, сейсмически пассивные кратоны, и новейшие платформы, для которых характерна рассеянная (рассредоточенная) сейсмичность (рис. 6). Границы этих структур в слое принимаются субвертикальными, но их конкретное пространственное положение может и должно быть уточнено на основе анализа конкретной тектонической структуры.

Сейсмические пояса - это объемные структурные элементы сейсмоактивного слоя. Их ширина больше (но не более чем в три раза) толщины сейсмоактивного слоя, а протяженность оценивается десятками тысяч километров. Толщина сейсмоактивного слоя в сейсмических поясах максимальная и иногда приближается к толщине упругого слоя литосферы. Очаги землетрясений в сейсмических поясах располагаются компактно. В кайнозойской тектонической структуре литосферы сейсмические пояса тяготеют к наиболее подвижным тектоническим поясам Земли.

Сейсмические пояса представляют собой сложные образования, и внутри них могут быть выделены структурные элементы третьего ранга - сегменты сейсмических поясов, что мы и видим на рис. 1. Протяженность этих структурных элементов достигает от нескольких сотен до первых тысяч километров. Это промежуточные структурные элементы сейсмических поясов, но вложены в структуру пояса как органически связанные мелкие элементы его внутреннего строения и отражают его делимость по простиранию.

Области рассеянной (рассредоточенной) сейсмичности - полностью антиподальные структурные элементы, но также объемные сейсмические структуры сейсмоактивного слоя. Их среднегеометрические размеры на два-три порядка превышают толщину сейсмоактивного слоя. В плане они более или менее изометричны. Толщина сейсмоактивного слоя здесь составляет лишь 15-30 \% толщины упругой литосферы. Очаги землетрясений 


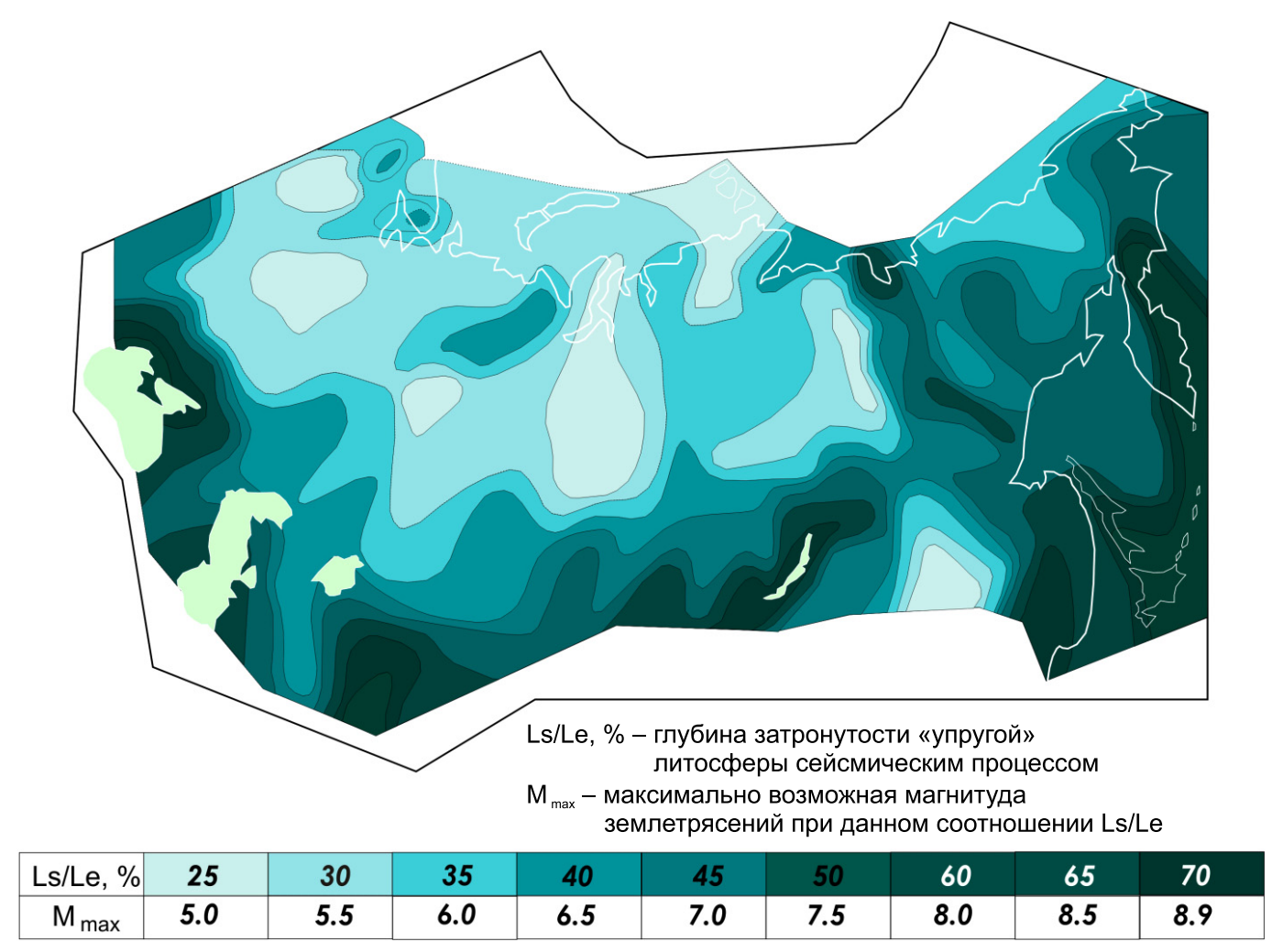

Рис. 7. Районирование территории СССР по сейсмической опасности [Levi, 1991].

I Fig. 7. Seismic hazard zoning of the USSR territory [Levi, 1991]

здесь рассредоточены, а частота сейсмических событий низких энергий в среднем не превышает первых десятков в столетие. В кайнозойской тектонической структуре области рассеянной (рассредоточенной) сейсмичности тяготеют к жестким внутриплитным пространствам. Среднегеометрические размеры сейсмически пассивных областей составляют тысячи километров, но, как правило, не выходят за рамки 10000 км.

Сейсмическими структурами четвертого ранга в сейсмических поясах выступают сейсмические зоны, представляющие собой узкие (первые десятки километров) и весьма протяженные (первые сотни километров) структурные элементы. Именно здесь обычно и наблюдается хотя и временное, но резкое утолщение сейсмоактивного слоя. Тяготеют сейсмические зоны в тектонической структуре литосферы к наиболее крупным глубинным разломам или системам подобных разломов, нередко являющихся составными частями межплитных границ. Именно здесь чаще, чем где-либо, формируются очаги наиболее сильных землетрясений. Сейсмические зоны не характерны для структурных элементов областей рассеянной (рассредоточенной) сейсмичности во внутриплитных пространствах.

Сейсмические структуры пятого ранга в сейсмоактивных поясах и областях рассеянной (рассредо- точенной) сейсмичности во внутриплитных пространствах - это сейсмические узлы. Они представляют собой небольшие по размерам (до 100 км) изометричные в плане скопления очагов землетрясений. В сейсмоактивных поясах сейсмические узлы, объединяясь, формируют узкие сейсмические зоны, в которых располагаются с довольно выдержанным шагом на некотором удалении друг от друга. Междуузлия отличаются от узлов уменьшением числа землетрясений, а иногда между узлами и внутри них наблюдаются «сейсмические окна» или «бреши». В областях рассеянной (рассредоточенной) сейсмичности во внутриплитных пространствах сейсмические узлы располагаются хаотически.

Сейсмоактивные структуры шестого ранга - сейсмические «линзы» - это собственно сейсмические очаги. Их форма обычно расшифровывается по анализу афтершоковых областей и зависит главным образом от формы той неоднородности литосферы, которая разрушается или разрушилась в результате конкретного сейсмического события.

Суммируя сказанное, используя соотношение параметров Le и LS, можно оценить потенциальную сейсмичность различных регионов исключительно по геофизическим и сейсмологическим данным (рис. 7). 


\section{4. СЕЙСМИЧЕСКИЙ КЛИМАТ, ПОГОДА И ИХ СОСТАВЛЯЮЩИЕ}

Неравномерность хода сейсмического процесса наводит на мысль о том, что мы имеем дело с временными аномалиями, тождественными аномалиям атмосферных процессов, т. е. временными изменениями погоды и климата, но в приложении к сейсмичности. Приведем определения «сейсмического климата» и его составляющих.

«Сейсмический климат» - это многолетний (десятки, сотни и тысячи лет) режим «сейсмической погоды» в том или ином регионе, определяемый его конкретными геодинамическими условиями. Представления о «сейсмическом климате» складываются на основе статистической обработки результатов исторических и инструментальных наблюдений. «Сейсмический климат» - одна из важнейших геофизических характеристик активных в геодинамическом отношении регионов, проявляющаяся в абсолютных, крайних и средних значениях повторяемости землетрясений, вариациях физических полей и флюидного потока из недр Земли, в изменениях ее напряженно-деформированного состояния. Именно изучение сейсмического климата может лежать в основе долго- и среднесрочного прогноза землетрясений высоких энергий.

«Сейсмическая погода» - некое состояние сейсмоактивной среды в конкретном месте и в конкретный момент или промежуток времени (сутки, месяцы, годы), обусловленное физическими процессами, происходящими при взаимодействии оболочек Земли и приводящими к тектоническим деформациям или физико-химическим преобразованиям вещества глубоких недр планеты. Именно эти характеристики при достаточном наборе статистических данных являются основой средне- и краткосрочного прогноза «сейсмической погоды». Никакие статистические или иные, чисто математические, «ухищрения», при отсутствии достаточного статистического материала в принципе не могут претендовать на краткосрочный прогноз «сейсмических штормов», под которыми здесь и в дальнейшем будут пониматься землетрясения мощностью 1016-1018 Дж.

\section{5. ВРЕМЕННОЙ ХОД СЕЙСМИЧНОСТИ В ПРИБАЙКАЛЬЕ ПО ДАННЫМ ИСТОРИЧЕСКИХ ХРОНИК И ИНСТРУМЕНТАЛЬНОГО МОНИТОРИНГА}

Анализ исторических хроник показывает ход изменения интенсивности сейсмического процесса в течение почти 300 лет (см. рис. 2). Всплески сейсмической активности происходят с интервалами времени 30-60 лет. Другая картина наблюдается по материалам сейсмического мониторинга 19602017 гг. (см. рис. 3).

Начнем с того, что деформационные процессы, приводящие к хрупкому разрушению упругой литосферы, в «твердой» Земле протекают медленно и, следовательно, изменения сейсмической погоды могут растягиваться на десятилетия, столетия и тысячелетия. Ниже остановимся на изменениях сейсмической погоды в Прибайкалье, опираясь только на результаты инструментальной регистрации сейсмических событий с энергетическими классами К>9 на отрезке 1960-2017 гг.

Вариации частоты возникновения землетрясений различных классов. Общее количество землетрясений произошедших в регионе за упомянутый срок составляет 17945 событий. Вклад в эту сумму вносят землетрясения с $K=9-17$. Посмотрим, как они распределялись по годам (рис. 8).

Видно, что частота сейсмических событий на протяжении почти 60 лет в целом нарастала (см. рис. 3 , красная кривая), хотя и испытывала достаточно резкие флуктуации в отдельные годы. Насколько достоверно это нарастание, судить трудно по причине изменений собственно в структуре сети сейсмостанций. За 1960-2017 гг. - количество станций то увеличивалось, то уменьшалось. В процессе развития сейсмической сети Прибайкалья совершенствовалось оборудование сейсмических станций, происходил переход на цифровую регистрацию событий, что в итоге приводило к увеличению числа регистрируемых землетрясений более низких энергетических классов. Теперь посмотрим динамику частоты сейсмических событий по энергетическим классам (рис. 9 и 10).

Анализ рис. 9 показывает, что частота проявления землетрясений с К=9-13 хорошо сопоставляется со временем активизации, но эта система резко нарушается начиная с землетрясений $\mathrm{K} \geq 14$ и для более высоких энергетических классов (рис. 10). Это может свидетельствовать о различии в механизмах формирования их очагов, которое ранее отмечал Ю.В. Ризниченко [Riznichenko, 1976c]. Он полагал, что землетрясения различных энергетических классов отличаются друг от друга по характеру разрушения упругого (сейсмоактивного) слоя. Он считал, что землетрясения с $\mathrm{K}=9-13$ возникают в результате хрупкого разрушения среды с образованием многочисленных непротяженных разрывов, тогда как землетрясения с $К \geq 14$ характеризуются сейсмотектоническим течением горных масс. Очаг как бы растекается в упругом слое литосферы по многочисленным трещинам. Однако при очень сильных землетрясениях очаг часто не успевает вписаться в объем сейсмоактивной среды и его «теоретическая» кровля 


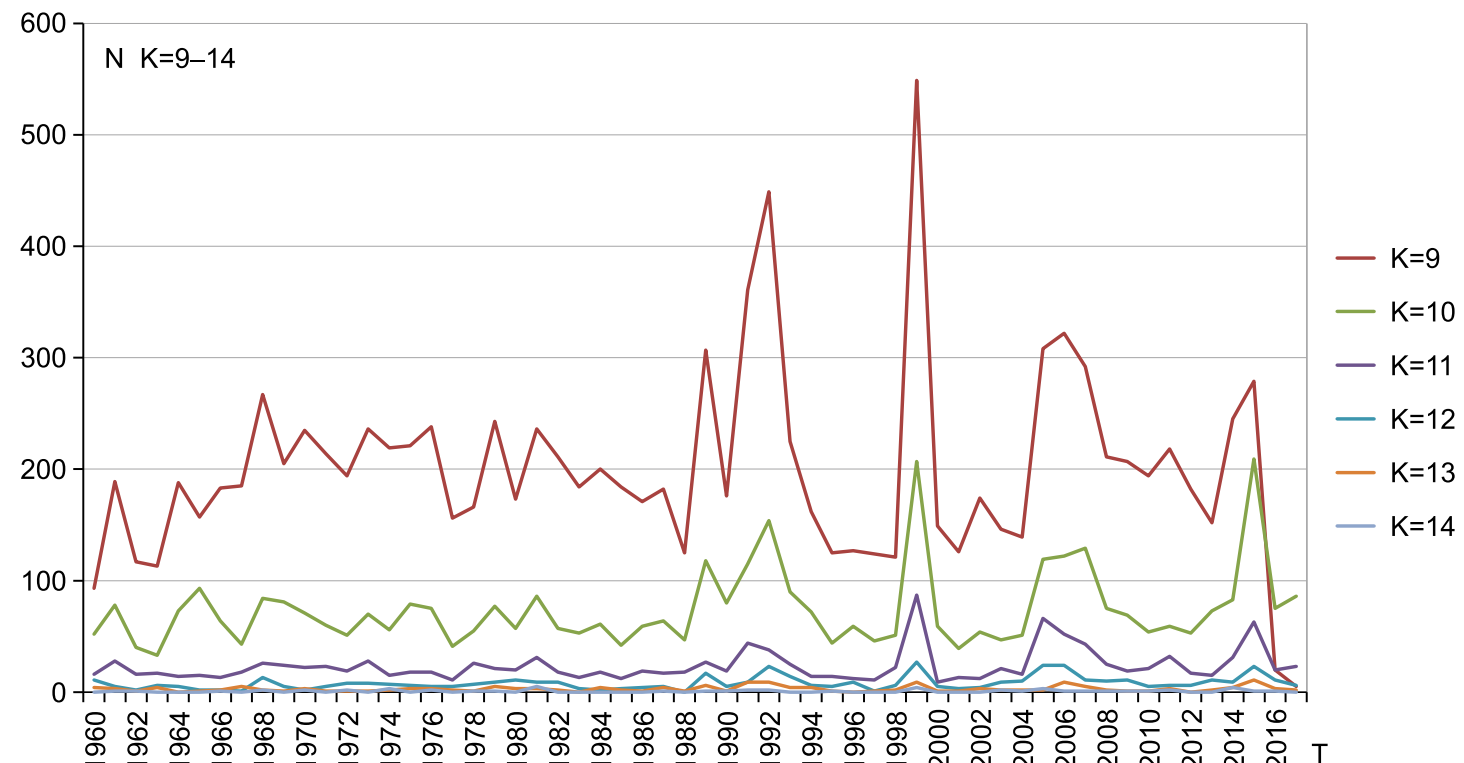

Рис. 8. Вариации частоты событий по годам для землетрясений низких энергетических классов с К=9-14.

| Fig. 8. Variations in the frequency of seismic events by years, considering the earthquakes of low energy classes, K=9-14.
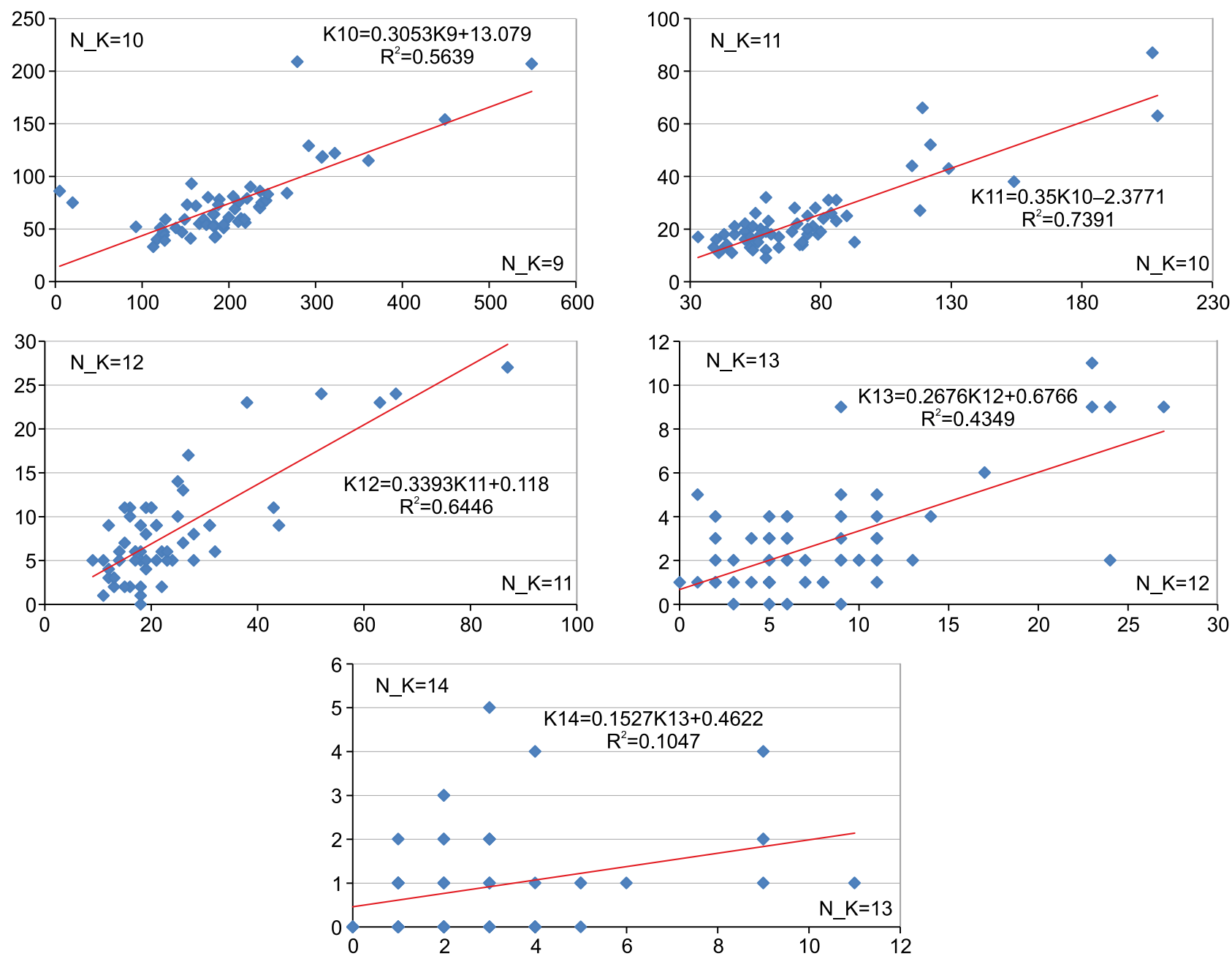

Рис. 9. Парные корреляционные отношения между количествами землетрясений с энергетическими классами $\mathrm{K}=9-13$.

Fig. 9. Pair correlations between the numbers of $K=9-13$ earthquakes. 


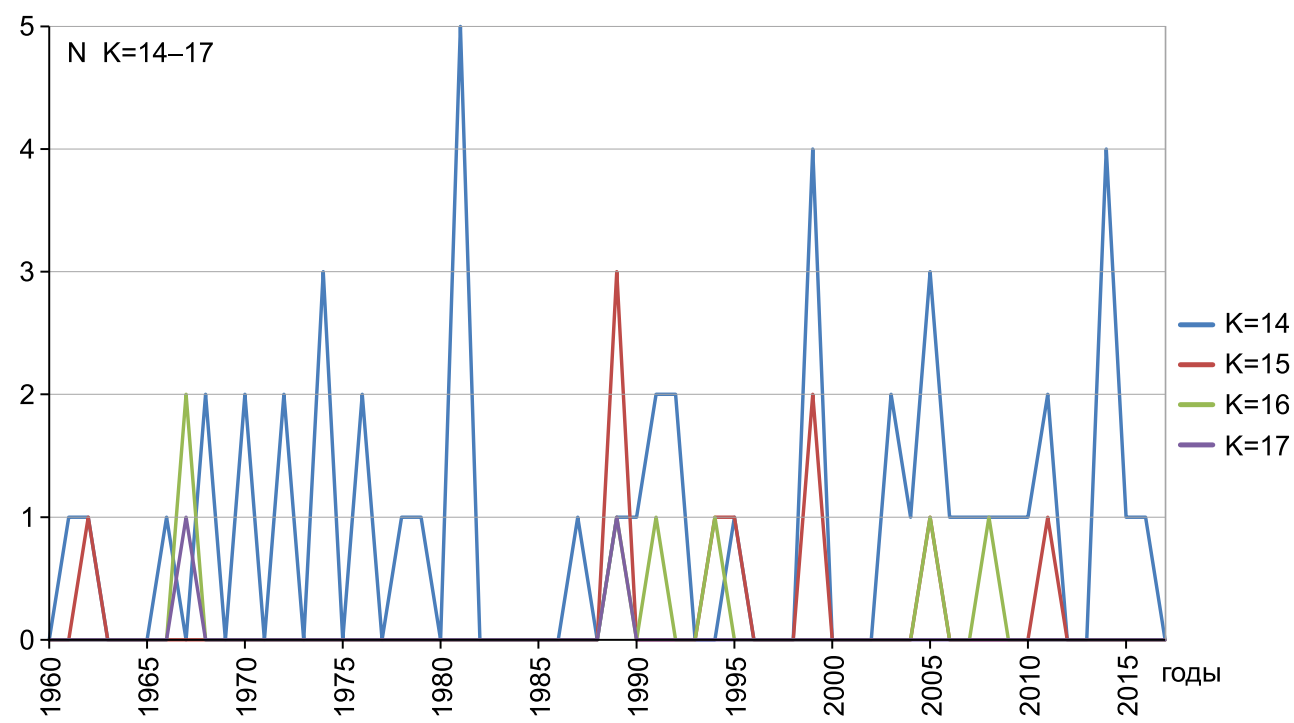

Рис. 10. Вариации частоты событий по годам для землетрясений высоких энергетических классов с К=14-17.

Fig. 10. Variations in the frequency of seismic events by years, considering the earthquakes of high energy classes, $K=14-17$.

выходит над поверхностью Земли и способствует образованию различных сейсмодислокаций, которые часто протягиваются на десятки и сотни километров.

На рис. 10 приведены вариации частоты проявления землетрясений К=14-17. Видно, что в большинстве случаев события $K=15,16$ и 17 ложатся во временные интервалы активизации сейсмических событий с $К=14$, хотя последние проявляются в более широких диапазонах времени и в некоторых случаях к максимумам их частоты приурочены события с К=15-17. Однако нередки случаи, когда в максимумах событий с К=14 более мощных землетрясений не наблюдалось.

Осмелимся предположить, что временные интервалы с максимумами событий К=14 могут ориентировать нас на возможное возникновение мощных землетрясений или проявление роевой сейсмичности, как это было в районе Северомуйского тоннеля в 1985-1990 гг. (рис. 11).

Относительная устойчивая периодичность сейсмических активизаций на протяжении почти 300 лет наводит на мысль, что они контролируются какими-то внешними причинами, а продолжительности периодов напоминают продолжительности вариаций солнечной активности. Кратко охарактеризуем доступные нам важнейшие составляющие космического климата.

\section{6. КОСМИЧЕСКАЯ ПОГОДА И КЛИМАТ}

Остановимся на некоторых определениях. В широком употреблении термины «космическая пого- да» и «космический климат» стали использоваться в 1990-х годах для описания наиболее важных аспектов науки о солнечно-земных связях и изучения совокупности взаимодействий гелио- и геофизических явлений. К космической погоде относится динамическая (с характерными временами сутки и менее) часть солнечно-земных связей, а по аналогии с земными процессами более продолжительные по времени (десятки, сотни лет) часто называются «космическим климатом». Одним из первых словосочетание «космическая погода» употребил А.Л. Чижевский в одной из своих публикаций начала XX в., а его доклад на биофизическом конгрессе был официальным признанием нового научного направления - гелиобиологии.

Солнечная активность - комплекс явлений и процессов, связанных с образованием и распадом в солнечной атмосфере сильных магнитных полей. Характеризуется числами Вольфа (W) - W=k(10g+f), где $\mathrm{k}$ - коэффициент, который подбирается для каждого телескопа; g - число групп пятен; f - общее число пятен (рис. 12).

Солнечные вспышки - взрывной процесс выделения энергии в атмосфере Солнца. Регистрация рентгеновского излучения Солнца, которое полностью поглощается атмосферой Земли, началась с запуска первого космического аппарата «Спутник-2» с соответствующей аппаратурой. Данные об интенсивности рентгеновского излучения солнечных вспышек до 1957 г. полностью отсутствуют. Вспышки охватывают все слои солнечной атмосферы: фотосферу, хромосферу и корону Солнца и характеризуются различными и независимыми проявлениями солнечной активности. Помесячные 


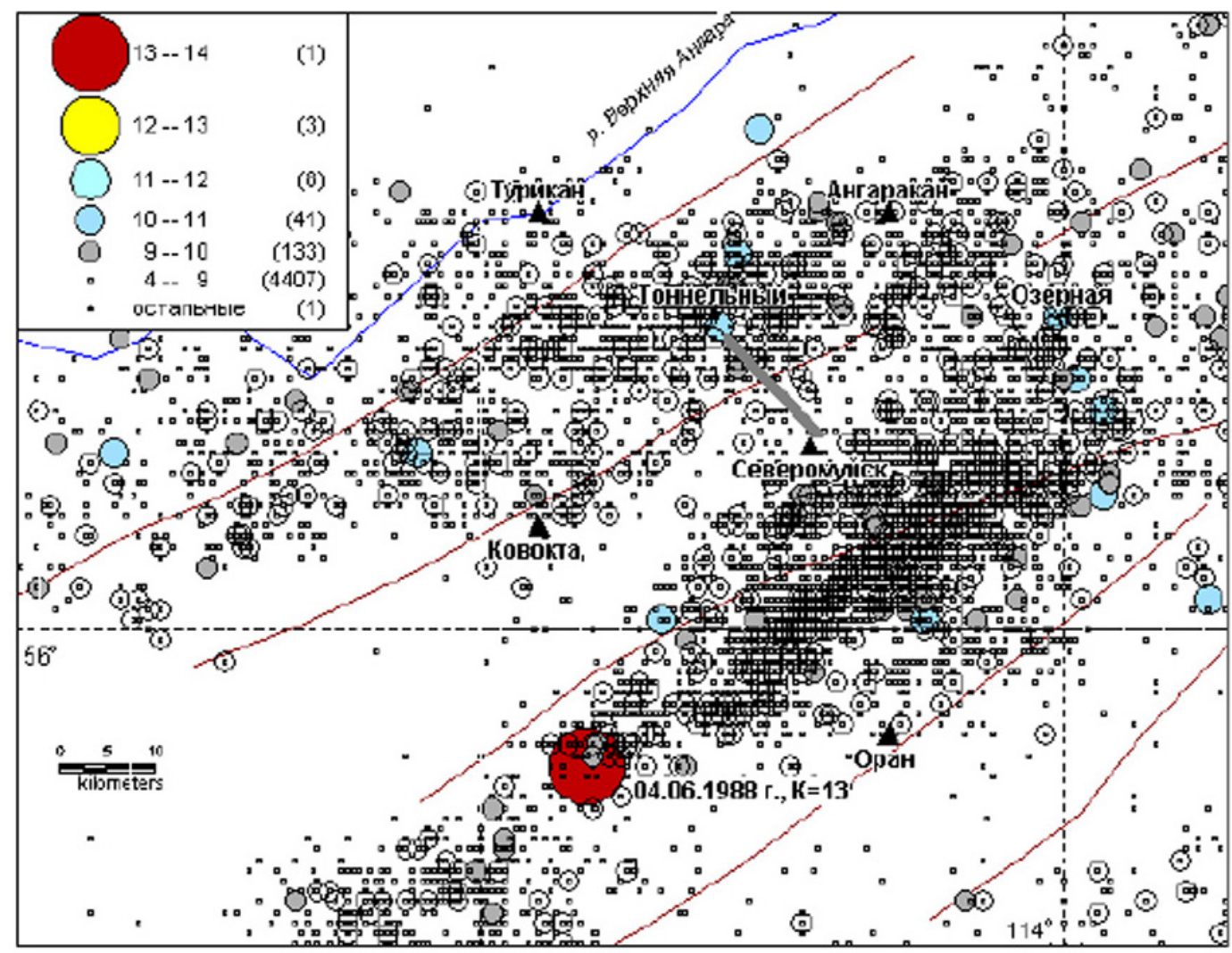

Рис. 11. Эпицентральное поле Ангараканского роя, район Северомуйского тоннеля, Северное Прибайкалье, 19851990 гг. Треугольники - сейсмические станции [Sankov et al., 1991; Semenov et al., 2011]. В верхнем левом углу условные обозначения: кружки - эпицентры землетрясений различных энергетических классов; в скобках - число сейсмических событий.

Fig. 11. The field of earthquake epicenters of the Angarakan swarm, the area near the Severomuisk tunnel, Northern Pribaikalie, 1985-1990. Triangle - seismic station [Sankov et al., 1991; Semenov et al., 2011]. Legend in the top left corner: dot - earthquake epicenter; number in brackets - quantity of seismic events.

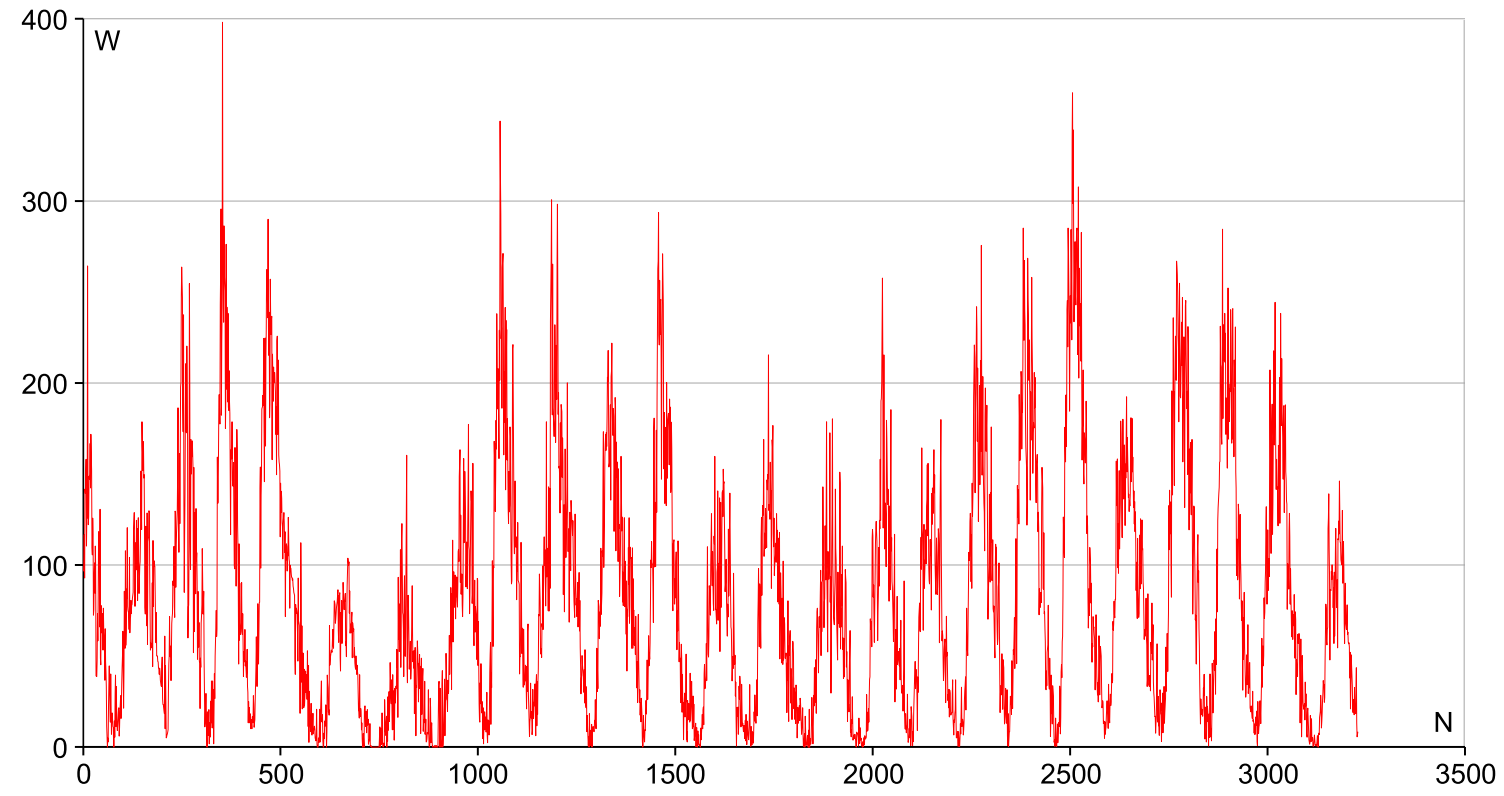

Рис. 12. Вариации солнечной активности в числах Вольфа W с 1749 по 2017 г. N на горизонтальной оси - месяцы.

Fig. 12. Solar activity variations in Wolf numbers, W from 1749 to 2017 . Numbers on the horizontal axis - months. 
вариации числа солнечных вспышек связаны с проявлениями солнечной активности (рис. 13). Энерговыделение мощной солнечной вспышки может достигать $6 \times 10^{25}$ Дж, что составляет около $1 / 6$ энергии, выделяемой Солнцем за секунду. Это соответствует объему мирового потребления электроэнергии за 1 миллион лет. Фотоны от вспышки достигают Земли примерно за 8.5 минуты. Мощные потоки заряженных частиц и облака плазмы от солнечной вспышки достигают планеты только через двое-трое суток.

Солнечный ветер - SW - поток ионизированных частиц гелиево-водородной плазмы, истекающий из солнечной короны в окружающее космическое пространство со скоростью 300-1200 км/с. Значение индекса $\boldsymbol{S} \boldsymbol{W}$ может лежать в интервале от 0 до 2000. Типичное значение - около 400. Чем выше скорость частиц, тем большее давление испытывает ионосфера. При значениях $S W$, превышающих 500 км/ч, солнечный ветер вызывает возмущение магнитного поля Земли, что в итоге приводит к разрушению ионосферного слоя $\boldsymbol{F}$, снижению уровня ионизации ионосферы и ухудшению условий прохождения электромагнитных волн на КВдиапазонах.

Полярные сияния - северное и южное - свечение верхних слоев атмосфер планет, обладающих магнитосферой, вследствие их взаимодействия с заряженными частицами солнечного ветра. Наблюдаются преимущественно в высоких широтах обоих полушарий в овальных зонах-поясах, окружающих магнитные полюсы Земли, - авроральных овалах, которые распространяются в пределах 67-70 широт в обоих полушариях. Диаметр авроральных овалов составляет 23000 км во время спокойного Солнца. В периоды высокой солнечной активности авроральный овал расширяется и полярные сияния могут наблюдаться на более низких широтах - на 20-25 южнее или севернее границ их обычного распространения, часто они возникают во время солнечных вспышек и геомагнитных бурь, являясь их индикаторами (рис. 14).

Геомагнитная активность - возмущения магнитного поля Земли, связанные с изменениями магнитосферно-ионосферной токовой системы. Геомагнитная активность является частью солнечно-земной физики и ее практической области космической погоды. К основным видам геомагнитной активности относятся сильные возмущения - магнитные суббури и магнитные бури, а также слабые возмущения - разнообразные типы магнитных пульсаций. Индексы $A p$ и K (A-Ind/KInd) характеризуют состояние магнитного поля Земли. Увеличение значения индекса К свидетельствует о его нарастающей нестабильности. Значения $\boldsymbol{K}$, превышающие 4 , означают наличие магнит- ной бури. В качестве базовой величины для определения динамики изменения значений индекса $\boldsymbol{K}$ используется индекс $\boldsymbol{A p}$ или $\boldsymbol{a \boldsymbol { a }}$ (рис. 15).

Значение этого параметра является производной величиной от уровня мощности солнечной энергии, измеряемой в гигаваттах, которая достигает полярных областей Земли. Параметр может принимать значения в интервале от 1 до 10. Чем больше уровень солнечной энергии, тем сильнее ионизация слоя ионосферы. Чем больше значение этого параметра, тем меньшую широту имеет граница авроральной шапки и тем выше вероятность возникновения полярных сияний. При высоких значениях параметра появляется возможность для проведения дальних радиосвязей на УКВ, но при этом полярные трассы на КВ частотах могут быть частично или полностью заблокированы.

Временные соотношения параметров космического климата и сейсмичности Прибайкалья. В нашем распоряжении имеются базы данных о вариациях по времени солнечной активности в числах Вольфа W с 1749 по 2017 г. [Sunspot Index..., 2018]; индексы геомагнитной активности - аaindex [Konstantinovskaya, 2013]; инструментальные данные о сейсмической активности Прибайкалья [The Main Catalog..., 2018].

Совместный анализ перечисленных характеристик приведен на рис. 16, из которого следует, что всплески сейсмической активности тяготеют к максимумам ухудшения космического климата, хотя и наблюдается небольшое по времени запаздывание максимумов относительно друг друга.

Несовпадение максимумов по времени обусловлено различной продолжительностью периодов активизаций или элементарным запаздыванием активизаций у различных процессов. Тем не менее открывается путь к прогнозированию сейсмической погоды. Влияние солнечной и геомагнитной активности на ход сейсмического процесса описывается многими исследователями [Sobolev et al., 2001; Zakrzhevskaya, Sobolev, 2002; Sycheva et al., 2011; Shestopalov, Yanke, 2008; Bokov, 2009; Korsunova et al., 2009; Adushkin et al., 2012; Shestopalov et al., 2013; Nesterov, 2013; и дp.].

Наличие периодичности в ходе развития процессов, охарактеризованных на рис. 12, позволяет путем суммирования гармоник построить статистические модели хода изменений солнечной, геомагнитной и сейсмической активности (рис. 17). Гистограммы сглажены путем линейной фильтрации окном 11 лет. В данном случае мы наблюдаем те же закономерности, что и на рис. 15, с той только разницей, что мы можем заглянуть в возможное будущее хода процессов до 2050 г.

Из рис. 17 следует, что в ближайшие десятилетия следует ожидать постепенного небольшого 


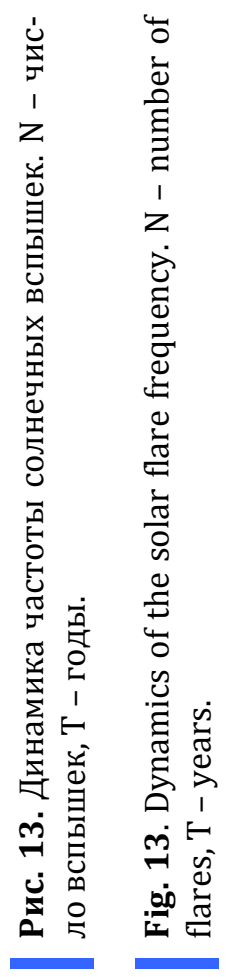

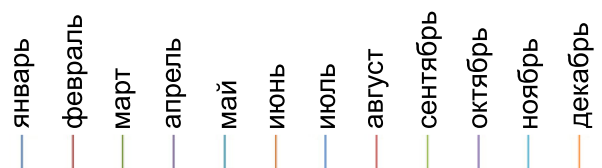

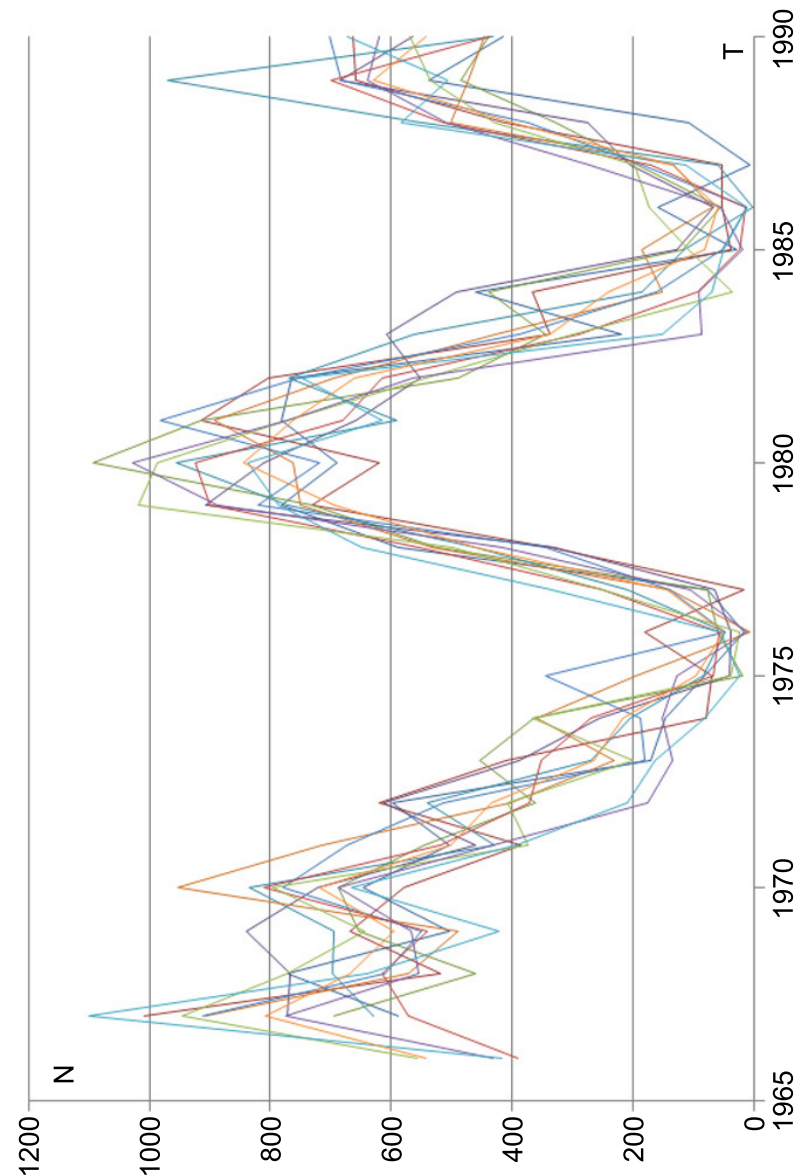

恣是 1.

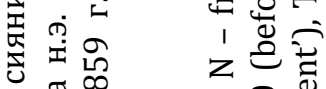

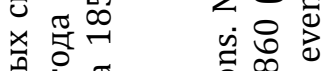

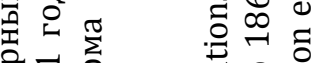

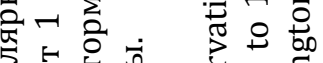

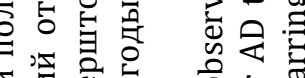

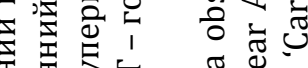

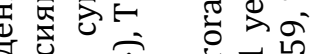

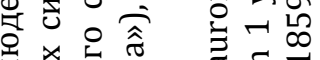

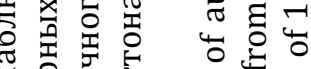

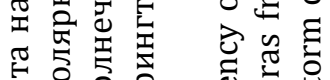

응 只

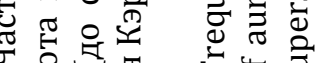

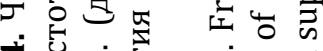

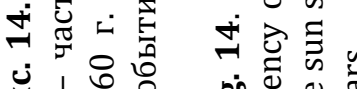

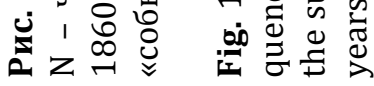

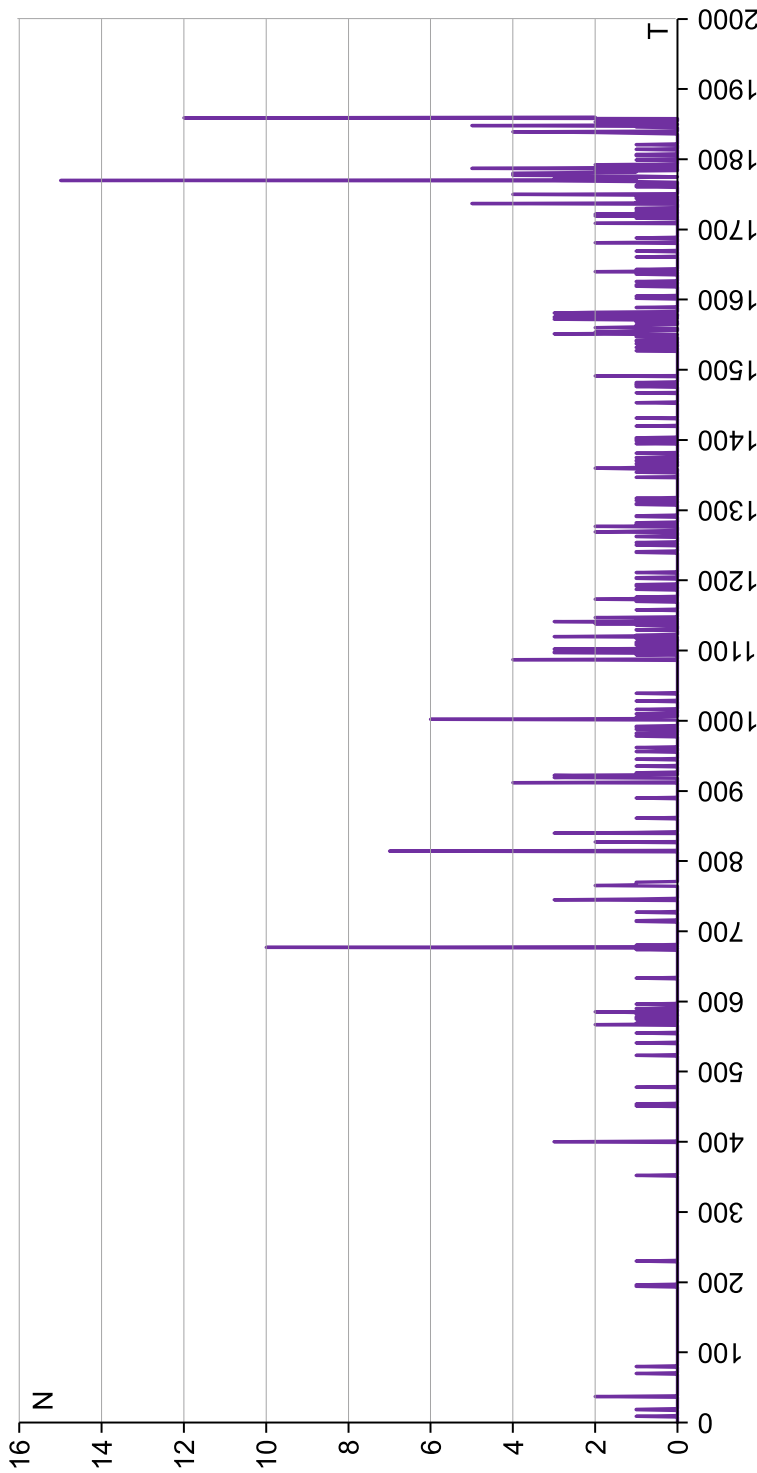



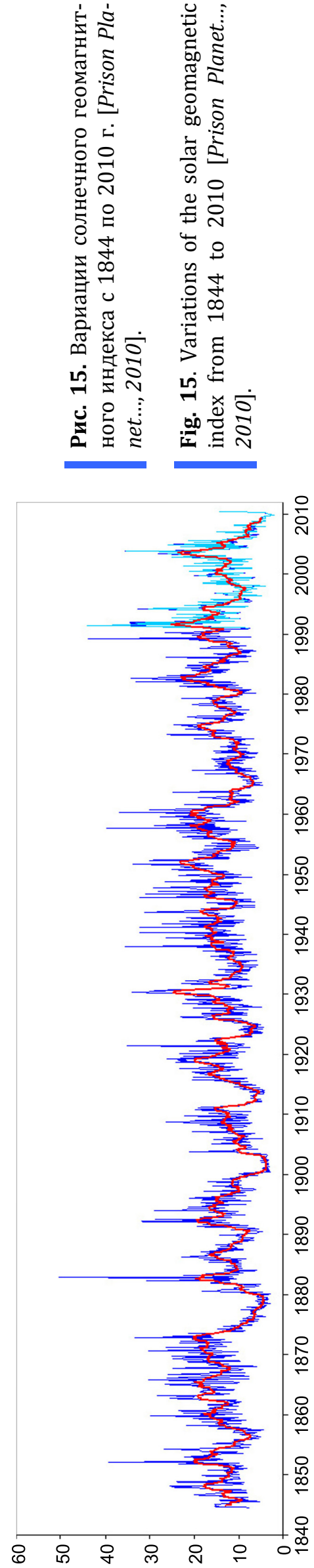

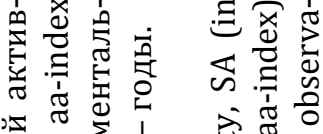

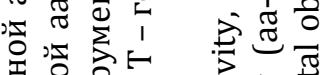

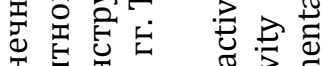

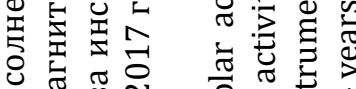

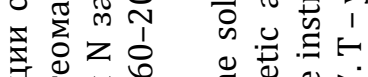

完边。

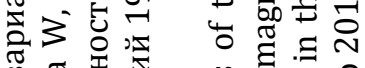

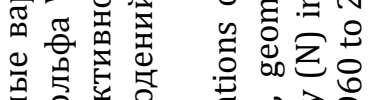

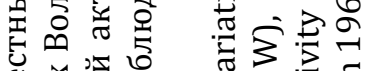

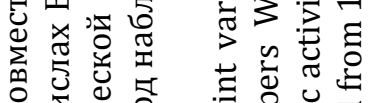

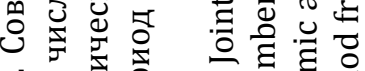

๑ $\sum_{0}^{5}$

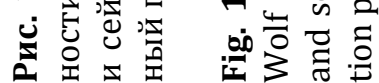

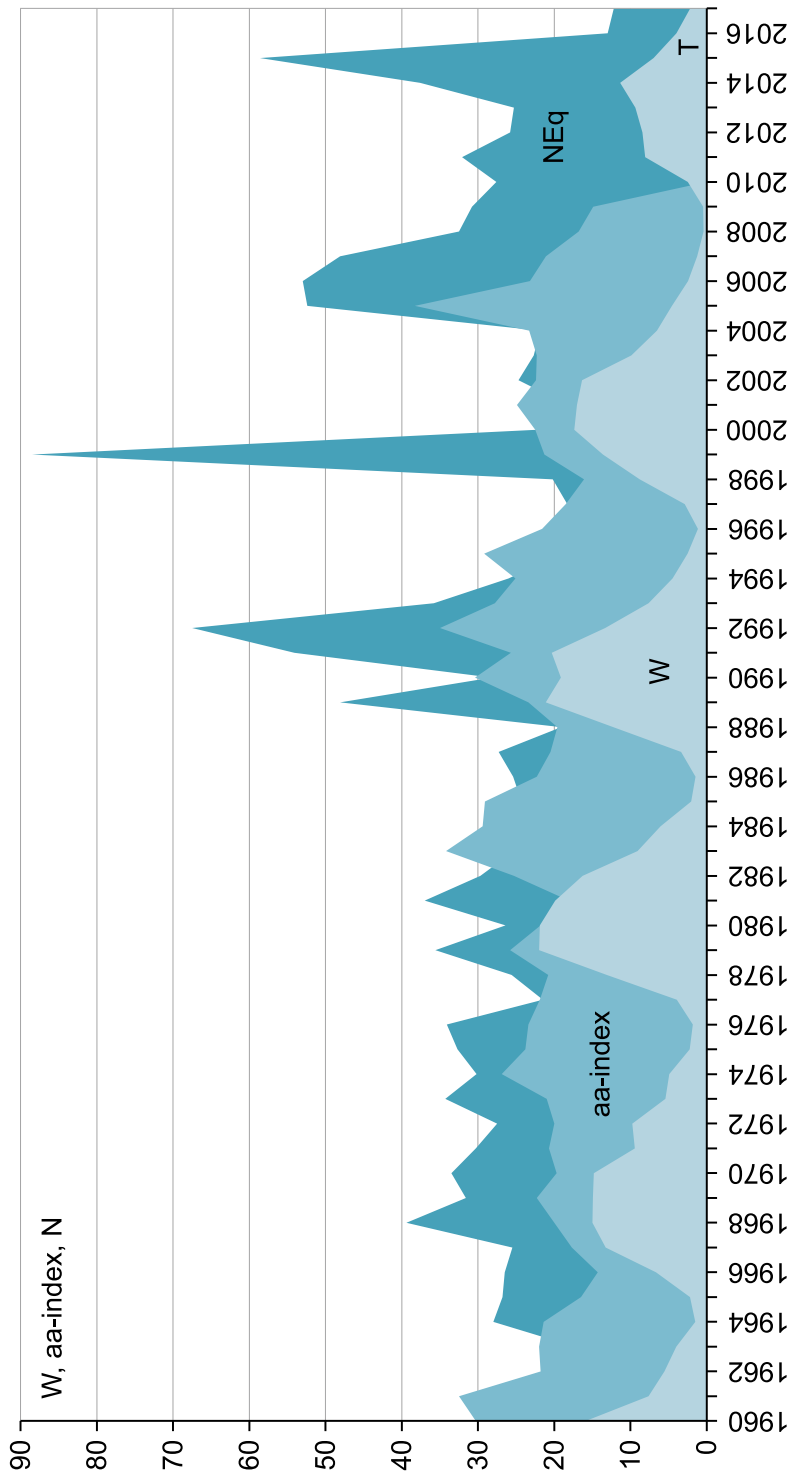



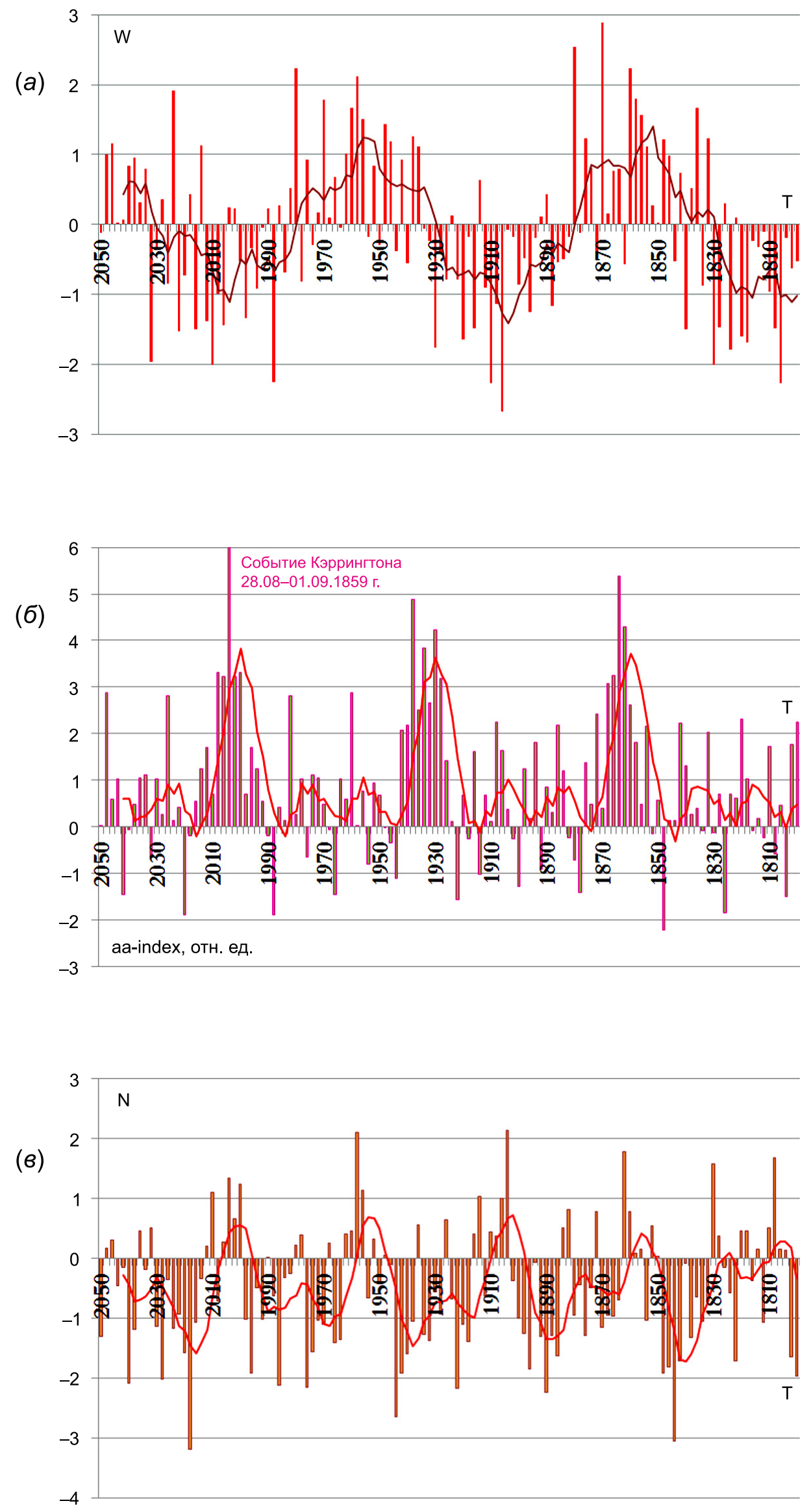

Рис. 17. Перспективы изменения солнечной активности $(a)$, геомагнитной активности (б) и сейсмической активности (в) в Прибайкалье.

I Fig. 17. Potential future changes in the solar activity (a), geomagnetic activity (б) and seismic activity ( $($ ) in Pribaikalie. 
увеличения солнечной и геомагнитной активности, но это не приведет к существенному повышению сейсмической активности в Прибайкалье.

\section{7. ЗАКЛЮЧЕНИЕ}

Из сказанного выше следует, что создание в ИЗК СО РАН лаборатории тектонофизики способствовало возникновению и развитию в институте нового научного направления, в рамках которого сложные природоведческие задачи стали решаться путем статистического анализа параметров среды и выявления ее закономерностей на числовой основе, ограничивающей полет научных фантазий.

В этой статье мы приходим к выводам, что:

- $\quad$ эпицентральное поле землетрясений в Прибайкалье структурировано;

- $\quad$ энергия землетрясений зависит от объема сейсмических очагов, а размеры поверхностных сейсмогенных структур контролируются энергией землетрясений и глубинами залегания гипоцентров очагов;

- энергия землетрясений зависит от соотношения толщины слоя упругой литосферы Le и сейсмоактивного слоя Ls, толщина последнего способна меняться во времени пропорционально скоростям деформаций литосферы и изменению плотности глубинного теплового потока;

- изменение магнитного поля Земли под воздействием солнечного излучения регулирует вариации сейсмической погоды.

\section{8. БЛАГОДАРНОСТИ}

Исследования проводятся в рамках Программы ИНЦ СО РАН «Фундаментальные исследования и прорывные технологии как основа опережающего развития Байкальского региона и его межрегиональных связей (0341-2015-0001)» и при поддержке РФФИ (проект № 17-57-44806-МОНГ-А).

\section{9. ЛИТЕРАTУРA / REFERENCES}

Adushkin V.V., Ryabova S.A., Spivak A.A., Kharlamov V.A., 2012. Response of the seismic background to geomagnetic variations. Doklady Earth Sciences 444 (1), 642-646. https://doi.org/10.1134/S1028334X12050157.

Bokov V.N., 2009. Short-term forecasting of earthquakes. Innovations (9), 90-91 (in Russian) [Боков В.Н. Краткосрочный прогноз землетрясений // Инновации. 2009. № 9. С. 90-91].

Konstantinovskaya L.V., 2013. Solar Activity (SA) (Tables) (in Russian) [Константиновская Л.В. Солнечная активность (СА) (таблицы). 2013]. Available from: http://www.astronom2000.info/ (last accessed March 3, 2018).

Korsunova L.P., Mikhailov Yu.M., Khegai V.V., Leshchenko L.N., Smirnov S.E., Bogdanov V.V., 2009. Experimental evidence of relationship between possible foreshocks in the surface quasi-static electric fields and in the ionosphere. Solnechno-Zemnaya Fizika (Solar-Terrestrial Physics) 14, 125-130 (in Russian) [Корсунова Л.П., Михайлов Ю.М., Хегай В.В., Лещенко Л.Н., Смирнов С.Э., Богданов В.В. Экспериментальное подтверждение взаимосвязи возможных предвестников землетрясений в приземных квазистатических электрических полях и в ионосфере // Солнечно-земная физика. 2009. Вып. 14. С. 125-130].

Levi K.G., 1987a. 'Seismic structures' of the lithosphere and tectonic movements. In: Top problems of modern geodynamics and deep structure of the USSR territory. Abstracts of the XX All-Union tectonic meeting. Moscow, p. 9 (in Russian) [Леви К.Г. «Сейсмические структуры» литосферы и тектонические движения // Актуальные проблемы современной геодинамики и глубинного строения территории СССР: Тезисы докладов XX Bсесоюзного тектонического совещания. М., 1987. С. 9].

Levi K.G., 1987b. Tectonic movements and seismically active (focal) layer of the continental lithosphere. In: Yu.M. Pushcharovsky (Ed.), Modern tectonic activity of the Earth and seismicity. Nauka, Moscow, p. 16-17 (in Russian) [Леви К.Г. Тектонические движения и сейсмоактивный (очаговый) слой континентальной литосферы // Современная тектоническая активность Земли и сейсмичность / Ред. Ю.М. Пущаровский. М.: Наука, 1987. C. 16-17].

Levi K.G., 1987c. Variations in the thickness of the continental lithosphere and vertical tectonic movements. In: Complex studies of the deep structure of the Earth's crust and upper mantle in East Siberia. Chita, p. 53-54 (in Russian) [Леви К.Г. Вариации толщины континентальной литосферы и вертикальные тектонические движения // Комплексные исследования глубинного строения земной коры и верхней мантии Восточной Сибири. Чита, 1987. С. 53-54].

Levi K.G., 1991. Neotectonic Movements in Seismically Active Zones of the Lithosphere. Nauka, Novosibirsk, 166 p. (in Russian) [Леви К.Г. Неотектонические движения в сейсмоактивных зонах литосферы. Новосибирск: Наука, 1991. 166 c.].

Levi K.G., 2007. «Seismic climate» and «Seismic weather»: what hopes for realization of various kinds of the forecast socially dangerous earthquakes? In: D. Ankhtsetseg, K.G. Levi, A. Schlupp, M. Ulziibat (Eds.), Proceedings of the conference commemorating the 50th anniversary of the 1957 Gobi-Altay Earthquake. Ulaanbaatar, Mongolia, p. 104-108. 
Levi K.G., 2014. Geodynamic activity of the lithosphere and problems of tectonophysics - outlook after 35 years. Geodynamics \& Tectonophysics 5 (2), 527-546 (in Russian) [Леви К.Г. Геодинамическая активность литосферы и некоторые проблемы тектонофизики - взгляд через 35 лет // Геодинамика и тектонофизика. 2014. Т. 5. № 2. C. 527-546]. https://doi.org/10.5800/GT-2014-5-2-0139.

Levi K.G., Chechelnitsky V.V., 2012. Problems of seismic safety of the Baikal region - 2011. Bulletin of the Buryatain Scientific Center SB RAS (1), 30-42 (in Russian) [Леви К.Г., Чечельницкий В.В. Проблемы сейсмобезопасности Байкальского региона - 2011 г. // Вестник Бурятского научного центра СО РАН. 2012. № 1. С. 30-42].

Map of Earthquake Epicenters of Baikal Region for the Period from 1950 to 2009 (in Russian) [Карта эпицентров землетрясений Прибайкалья за период 1950-2009 гг.]. Available from: http://geophys.aari.ru/uv/Project \%20AARI_GCRSA.pdf/ (last accessed April 12, 2018).

Medvedev S.V., Sponheuer V., Karnik V., 1965. Seismic Intensity Scale MSK-64. USSR Acad. Sci., Moscow, 1965.15 p (in Russian) [Медведев С.В. Шпонхойер В., Карник В. Шкала сейсмической интенсивности МSK-64. М.: МГК АН CCCP, 1965. 15 c.].

Nesterov V.I., 2013. Effects in the lower ionosphere during seismotectonic processes. Review. Scientific Notes of the Pacific State University 4 (4), 1274-1286 (in Russian) [Нестеров В.И. Эффекты в нижней ионосфере при сейсмотектонических процессах. Обзор // Ученые заметки ТОГУ. 2013. Т. 4. №4. С. 1274-1286].

Prison Planet, 2010. Solar geomagnetic index reaches unprecedented low - only «zero» could be lower - in a month when sunspots became more active. Available from: https://www.prisonplanet.com/solar-geomagnetic-indexreaches-unprecedented-low---only-“zero"-could-be-lower---in-a-month-when-sunspots-became-more-active.html (last accessed: May 28, 2018).

Riznichenko Yu.V., 1976a. Dimensions of an earthquake source in the crust and seismic moment. In: Yu.V. Riznichenko (Ed.), Studies in earthquake physics. Nauka, Moscow, p. 9-26 (in Russian) [Ризниченко Ю.В. Размеры очага корового землетрясения и сейсмический момент // Исследования по физике землетрясений / Ред. Ю.В. Ризниченко. М.: Наука, 1976. С. 9-26].

Riznichenko Yu.V., 1976b. Extensive earthquake source and the seismotectonic flow of rock masses. In: Yu.V. Riznichenko (Ed.), Studies in earthquake physics. Nauka, Moscow, p. 236-262 (in Russian) [Ризниченко Ю.В. Протяженный очаг и сейсмотектоническое течение горных масс // Исследования по физике землетрясений / Ред. Ю.В. Ризниченко. М.: Наука, 1976. С. 236-262].

Riznichenko Yu.V. (Ed.), 1976c. Studies in earthquake physics. Nauka, Moscow, 289 p. (in Russian) [Исследования по физике землетрясений / Ред. Ю.В. Ризниченко. М.: Наука, 1976. 289 с.].

Sankov V.A., Dneprovsky Yu.I., Kovalenko S.N., Bornyakov S.A., Gileva N.A., Gorbunova N.G., 1991. Faults and Seismicity of the Northern Muya Geodynamic Polygon. Nauka, Novosibirsk, 111 p. (in Russian] [Саньков В.А., Днепровский Ю.И., Коваленко С.Н., Борняков С.А., Гилева Н.А., Горбунова Н.Г. Разломы и сейсмичность Северо-Муйского геодинамического полигона. Новосибирск: Наука, 1991. 111 с.].

Semenov R.M., Klyuchevsky A.V., Chernykh E.N., 2011. Quantitative estimation of dynamic parameters of earthquakes for constructing a geomechanical model of the Northern Muya tunnel. Modern Technologies. System Analysis. Modeling (2), 156-169 (in Russian) [Семенов Р.М., Ключевский А.В., Черных E.Н. Количественная оценка динамических параметров землетрясений для построения геомеханической модели Северомуйского тоннеля // Современные технологии. Системный анализ. Моделирование. 2011. № 2. С. 156-169].

Shebalin N.V., 1971. On the limiting magnitude and ultimate magnitude of earthquakes. Izvestiya AN SSSR, Seriya Fizika Zemli (6), 12-20 (in Russian) [Шебалин H.B. О предельной магнитуде и предельной балльности землетрясений // Известия АН СССР, серия Физика Земли. 1971. № 6. С. 12-20].

Shebalin N.V., Arefiev S.S., Tatevossian R.E., 1987. On the "own" structures of seismicity. In: Top problems of modern geodynamics and deep structure of the USSR territory. Abstracts of the XX All-Union tectonic meeting. Moscow, p. 18 (in Russian) [Шебалин Н.В., Арефьев С.С., Татевосян Р.Э. О собственных структурах сейсмичности // Актуальные проблемы современной геодинамики и глубинного строения территории СССР: Тезисы докладов XX Всесоюзного тектонического совещания. М., 1987. С. 18].

Sherman S.I., Dem'yanovich V.M., Lysak S.V., 2002. New data on recent destruction of lithosphere in the Baikal rift zone. Doklady Earth Sciences 387 (9), 1067-1070.

Sherman S.I., Zlogodukhova O.G., 2011. Seismic belts and zones of the Earth: formalization of notions, positions in the lithosphere, and structural control. Geodynamics \& Tectonophysics 2 (1), 1-34 (in Russian) [Шерман С.И., Злогодухова О.Г. Сейсмические пояса и зоны Земли: формализация понятий, положение в литосфере и структурный контроль // Геодинамика и тектонофизика. 2011. Т. 2. № 1. С. 1-34]. https://doi.org/10.5800/GT-20112-1-0031.

Shestopalov I.P., Belov S.V., Soloviev A.A., Kuzmin Y.D., 2013. Neutron generation and geomagnetic disturbances in connection with the Chilean earthquake of February 27, 2010 and a volcanic eruption in Iceland in March - April 2010. Geomagnetism and Aeronomy 53 (1), 124-135. https://doi.org/10.1134/S0016793213010179.

Shestopalov I.P., Yanke V.G., 2008. On the relationship between the Earth's endogenous activity and the solar activity, and ground-based monitoring of neutrons for developing a new approach to prediction of earthquakes, volcanic eruptions and other natural disasters (in Russian] [Шестопалов И.П., Янке В.Г. О взаимосвязи эндогенной активности Земли с солнечной активностью и наземный мониторинг нейтронов для разработки нового 
подхода прогнозирования землетрясений, вулканических извержений и других неблагоприятных природных явлений. 2008]. Available from: http://geophys.aari.ru/uv/Project\%20AARI_GCRSA.pdf/ (last accessed: April 10, 2018).

Sobolev G.A., Zakrzhevskaya N.A., Kharin E.P., 2001. On the relation between seismicity and magnetic storms. Izvestiya, Physics of the Solid Earth 37 (11), 917-927.

Sunspot Index and Long-term Solar Observations, 2018. Available from: http://www.sidc.be/silso/datafiles (last accessed: May 5, 2018).

Sycheva N.A., Bogomolov L.M., Sychev V.N., 2011. On geoeffective solar flares and variations of the seismic noise level. Izvestiya, Physics of the Solid Earth 47 (3), 207-222. https://doi.org/10.1134/S1069351310101027.

The Main Catalog of Earthquakes, 2018. Baikal Branch of Federal Research Center “GS RAS” (in Russian) [Ocновной каталог землетрясений. Байкальский филиал ФИЦ ЕГС РАН, 2018]. Available from: http://www.seisbykl.ru/modules.php (last accessed May 10, 2018).

Zadonina N.V., Levi K.G., 2008. Chronology of Natural and Social Phenomena in Siberia and Mongolia. Publishing House of the Irkutsk State University, Irkutsk, 760 p. (in Russian) [Задонина Н.В., Леви К.Г. Хронология природных и социальных феноменов в Сибири и Монголии. Иркутск: Изд-во ИГУ, 2008. 760 с.].

Zakrzhevskaya N.A., Sobolev G.A., 2002. On the seismicity effect of magnetic storms. Izvestiya, Physics of the Solid Earth 38 (4), 249-261.

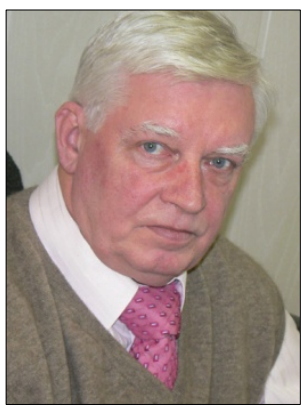

Кирилл Георгиевич Леви, докт. геол.-мин. наук, профессор

Институт земной коры СО РАН

664033, Иркутск, ул. Лермонтова, 128, Россия

$\bigotimes$ e-mail: levi@crust.irk.ru

ORCID ID https://orcid.org/0000-0003-2831-9120

Kirill G. Levi, Doctor of Geology and Mineralogy, Professor Institute of the Earth's Crust, Siberian Branch of RAS

128 Lermontov street, Irkutsk 664033, Russia

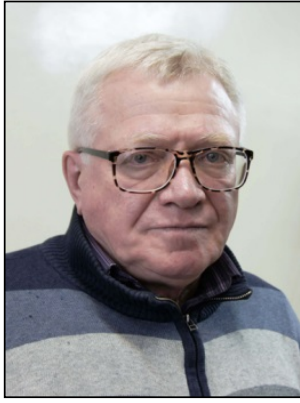

Андрей Иванович Мирошниченко, канд. геол.-мин. наук, с.н.с.

Институт земной коры СО РАН

664033, Иркутск, ул. Лермонтова, 128, Россия

e-mail: mai@crust.irk.ru

ORCID ID https://orcid.org/0000-0003-2749-8825

Andrei I. Miroshnichenko, Candidate of Geology and Mineralogy, Senior Researcher Institute of the Earth's Crust, Siberian Branch of RAS

128 Lermontov street, Irkutsk 664033, Russia

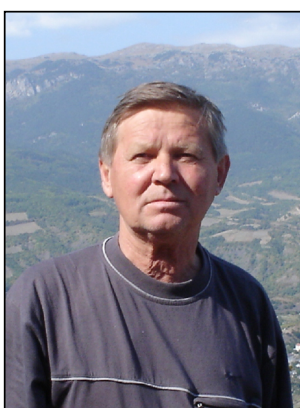

Владимир Васильевич Чечельницкий, канд. геол.-мин. наук, зам. директора по научной работе Байкальский филиал Федерального исследовательского центра «Единая геофизическая служба РАН» 664033, Иркутск, ул. Лермонтова, 128, Россия

e-mail: chechel@crust.irk.ru

Vladimir V. Chechelnitsky, Candidate of Geology and Mineralogy, Deputy Director for Science Baikal Branch of Federal Research Center 'Geophysical Survey of RAS'

128 Lermontov street, Irkutsk 664033, Russia 


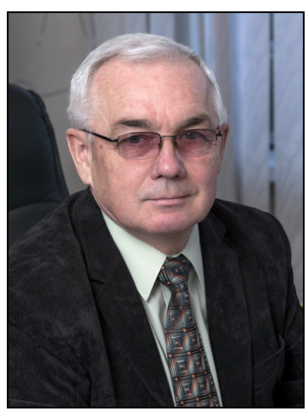

Геннадий Михайлович Ружников, докт. техн. наук, заведующий отделением Институт динамики систем и теории управления им. В.М. Матросова СО РАН 664033, Иркутск, ул. Лермонтова, 134, Россия

e-mail: rugnikov@icc.ru

Gennadiy M. Ruzhnikov, Doctor of Technical Sciences, Head of Department

V.M. Matrosov Institute for System Dynamics and Control Theory, Siberian Branch of RAS

134 Lermontov street, Irkutsk 664033, Russian 